\title{
Transactions
}

Cite this: Dalton Trans., 2011, 40, 9347

wWW.rsc.org/dalton

PERSPECTIVE

\section{Chemistry of polynuclear transition-metal complexes in ionic liquids}

\author{
Ejaz Ahmed ${ }^{a, b}$ and Michael Ruck*a,b \\ Received 4th May 2011, Accepted 1st June 2011 \\ DOI: 10.1039/c1dt10829h
}

\begin{abstract}
Transition-metal chemistry in ionic liquids (IL) has achieved intrinsic fascination in the last few years. The use of an IL as environmental friendly solvent, offers many advantages over traditional materials synthesis methods. The change from molecular to ionic reaction media leads to new types of materials being accessible. Room-temperature IL have been found to be excellent media for stabilising transitionmetal clusters in solution and to crystallise homo- and heteronuclear transition-metal complexes and clusters. Furthermore, the use of IL as solvent provides the option to replace high-temperature routes, such as crystallisation from the melt or gas-phase deposition, by convenient room- or low-temperature syntheses. Inorganic IL composed of alkali metal cations and polynuclear transition-metal cluster anions are also known. Each of these areas will be discussed briefly in this contribution.
\end{abstract}

\section{Introduction}

Ionic liquids (IL), defined as molten salts with melting points below $100{ }^{\circ} \mathrm{C}$, have received a lot of attention from both academia and industry during the last decade. ${ }^{1-3}$ They exhibit intrinsically promising characteristics such as wide liquid range,

${ }^{a}$ Department of Chemistry and Food Chemistry, Dresden University of Technology, D-01062, Dresden, Germany

${ }^{b}$ Max Planck Institute for Chemical Physics of Solids, Nöthnitzer Str. 40, 01187, Dresden, Germany. E-mail: Michael.Ruck@tu-dresden.de negligible vapour pressure, large electrochemical window, and high electric conductivity. ${ }^{4}$ These molten salts are being applied extensively as convenient solvents for organic and inorganic synthesis, ${ }^{4}$ for crystal engineering of coordination compounds, ${ }^{5-11}$ for liquid-liquid extraction, ${ }^{12}$ for electrodeposition, ${ }^{13}$ for spectroscopic studies, ${ }^{14}$ as electrolyte in photovoltaic devices (solar cells) ${ }^{15}$ and as a constituent in hybrid materials. ${ }^{16}$ Moreover, transitionmetal containing IL are regarded as potential materials that combine the properties of IL with additional inherent magnetic, optical or catalytic properties. ${ }^{17-21}$ A significant and distinctive feature of IL is the tunability of their chemical and physical

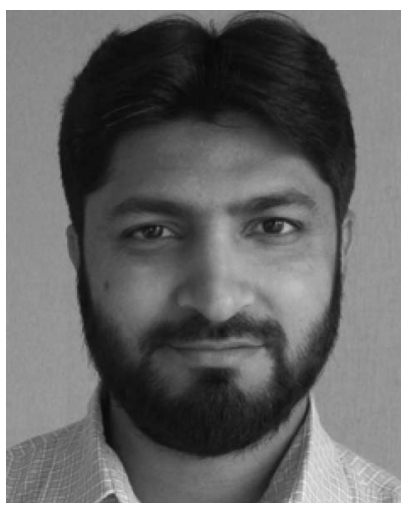

Ejaz Ahmed
Ejaz Ahmed obtained his first degree in Chemistry in 2004 and an M.Phil in analytical and inorganic chemistry in 2006 under the supervision of Prof. Muhammad Mazhar at Quaidi-Azam University, Pakistan. In 2007, he was awarded a PhD scholarship by the Higher Education Commission of Pakistan (HEC) and the German Academic Exchange Service $(D A A D)$; then he joined the research group of Prof. Michael Ruck at Dresden University of Technology, Germany. His current research is focused on the synthesis and crystal engineering of polynuclear metal clusters, low-dimensional conductors, and maingroup polycations from room-temperature ionic liquids.

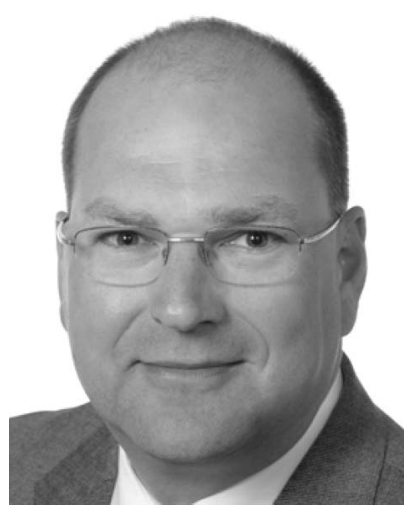

Michael Ruck
Michael Ruck obtained his diploma in chemistry in the group of Hartmut Bärnighausen at the University of Karlsruhe (Germany) in 1989. Then he joined the group of Arndt Simon at the Max Planck Institute for Solid State Research working on cluster compounds of the rareearth metals and completing his doctoral degree at the University of Stuttgart in 1991. He returned to Karlsruhe, where he completed his habilitation on ternary bismuth subhalogenides in 1997. Since 2000 he held the Chair for Inorganic Chemistry at Dresden University of Technology. In 2010, he became a Fellow of the Max Planck Society. His research interests concern subvalent compounds, low-dimensional systems, metastable phases, low-temperature syntheses of inorganic materials, and pseudo-symmetry in crystal structures. 
properties by selecting an appropriate combination of cation and anion.

There are several classical routes available to synthesise polynuclear transition-metal compounds. Mostly, they had been synthesised employing either higher temperature reactions (crystallisation from melt or chemical vapour transport $)^{22-31}$ or by treating the precursors in some organic solvents (non-polar, e.g. ether or benzene, or polar, e.g. dichloromethane or acetonitrile) $)^{32-34}$ or inorganic solvents (e.g. water or aqueous $\mathrm{HCl}){ }^{35}$

In the late 1980s, Hussey and co-workers introduced roomtemperature ionic liquids (RTIL) for stabilising both monomeric and polymeric chlorido complexes of transition metals. ${ }^{36}$ In many cases, RTIL proved to be superior to conventional molecular solvents such as water or acetonitrile, because the solvation and solvolysis pathways that are often available to these complexes in molecular solvents are absent in RTIL. Moreover, Hussey et al. also managed to investigate the spectroscopic and electrochemical properties of some of the transition-metal chloride clusters. ${ }^{37-39}$ Later, Hughbanks et al. reported a novel procedure, using RTIL to isolate the centred hexanuclear zirconium halogenide cluster compounds and studied their spectroscopic, electrochemical and structural properties. ${ }^{40-43}$ Following the same procedure, Köckerling et al. and Saito et al. synthesised some new centred hexanuclear zirconium halogenide clusters and trinuclear rhenium halogenide clusters, respectively. ${ }^{44,45}$ Mudring and co-workers synthesised a number of new salt-like structures from IL, containing lanthanides in the anionic network and investigated their structural and physical properties. ${ }^{8-11}$ Dyson et al., Raubenheimer et al., Xia et al., and Xiao et al. used IL as reagent and solvent to prepare several new organometallics. ${ }^{46}$ Dyson et al. also studied catalytic properties of transition-metal carbonyl clusters in IL. ${ }^{46 a, 47}$ Nockemann and co-workers obtained some polynuclear metal complexes from task-specific or functionalised IL. ${ }^{48}$

In our recent articles, we have demonstrated a facile and convenient room-temperature route for the synthesis of transitionmetal clusters and main group clusters employing RTIL as the reaction media. ${ }^{49-53}$ With respect to cluster chemistry, RTIL proved to be especially useful because of their good solubility for ionic compounds, redox stability, and thereof resulting opportunity to use reducing agents of various strengths. Moreover, controllable parameters, such as solvent acidity, oxidizing/reducing agents, and halide acceptors facilitate to produce transition-metal cluster compounds. The synthesis at room-temperature also widely eliminates the risk of product decomposition.

Although there are some interesting reviews or perspectives focused on selected topics in materials synthesis using IL, ${ }^{54-59}$ an updated account on polynuclear transition-metal complexes is still lacking, especially considering that the field is progressing relatively fast. Therefore, the main focus of this contribution is to highlight systematically some recent advances with some relevant past in the synthesis of discrete polynuclear transitionmetal clusters and complexes in IL and to outline new research on transition-metal chemistry. Briefly, the modes of synthesis and the structures of the well characterised compounds will be discussed. For convenience, metal clusters or complexes are categorised and discussed with respect to the number of metal atoms present in the structure. This perspective does not intend to be extensive or all-inclusive, but aims to provide a general overview of the field and to prompt future research efforts.

\section{Binuclear complexes}

Nockemann and co-workers developed carboxyl-functionalised IL that are able to dissolve considerable amounts of a wide range of metal oxides, including rare-earth oxides. ${ }^{48,60}$ Such IL are of particular interest for applications in the nuclear fuel cycle, especially, for the extraction of uranium from ores and for the processing of spent nuclear fuel rods.59,61 Nockemann et al. reported different metal complexes formed upon dissolution of corresponding metal oxides and hydroxides in different $\mathrm{IL}$, functionalised with a carboxyl group, e.g. [Hbet][ $\left.\mathrm{Tf}_{2} \mathrm{~N}\right]$, $\left[\right.$ HbetmIm] $\left[\mathrm{Tf}_{2} \mathrm{~N}\right]$, [HbetmMor] $\left[\mathrm{Tf}_{2} \mathrm{~N}\right]$ and [HbetmPyr][Tf $\left.{ }_{2} \mathrm{~N}\right]$. $\mathrm{X}$-Ray diffraction studies on single crystals of the metal complexes revealed a rich structural variety with strong dependence on the cationic core attached to the carboxylate groups. The task-specific betainium IL produced a number of polynuclear complexes. All these complexes were incorporated with zwitterionic carboxylate ligands and $\left[\mathrm{Tf}_{2} \mathrm{~N}\right]^{-}$counterions. Besides, the structural determination of single crystals of the complexes crystallised from these IL, the measurement of absorption and luminescence spectra of the metal complexes were also carried out. Taskspecific IL were used to synthesise different binuclear complexes, e.g. $\left.\left.\left[\left(\mathrm{UO}_{2}\right)_{2} \text { (bet }\right)_{6}\left(\mathrm{H}_{2} \mathrm{O}\right)_{2}\right]\left[\mathrm{Tf}_{2} \mathrm{~N}\right]_{4}, \quad\left[\mathrm{Cu}_{2} \text { (betmMor }\right)_{4}\right]\left[\mathrm{Tf}_{2} \mathrm{~N}\right]_{4}$, $\left.\left[\mathrm{Eu}_{2} \text { (betmMor }\right)_{6}\left(\mathrm{H}_{2} \mathrm{O}\right)_{2}\right]\left[\mathrm{Tf}_{2} \mathrm{~N}\right]_{6}, \quad\left[\mathrm{Cu}_{2}(\text { betmPyr })_{4}\left(\mathrm{H}_{2} \mathrm{O}\right)_{2}\right]\left[\mathrm{Tf}_{2} \mathrm{~N}\right]_{4}$, $\left[\mathrm{Cu}_{2}(\text { betmIm })_{4}\left(\mathrm{H}_{2} \mathrm{O}\right)_{2}\right]\left[\mathrm{Tf}_{2} \mathrm{~N}\right]_{4} \cdot \mathrm{H}_{2} \mathrm{O}, \quad\left[\mathrm{Cd}_{2}(\text { betPy })_{2}\left(\mathrm{H}_{2} \mathrm{O}\right)_{2}\right]\left[\mathrm{Tf}_{2} \mathrm{~N}\right]_{2}$, $\left[\mathrm{Eu}_{2}(\text { bet })_{8}\left(\mathrm{H}_{2} \mathrm{O}\right)_{4}\right]\left[\mathrm{Tf}_{2} \mathrm{~N}\right]_{6}, \quad\left[\mathrm{Eu}_{2}(\text { bet })_{8}\left(\mathrm{H}_{2} \mathrm{O}\right)_{2}\right]\left[\mathrm{Tf}_{2} \mathrm{~N}\right]_{6} \cdot 2 \mathrm{H}_{2} \mathrm{O}$ or $\left[\mathrm{Y}_{2}(\text { bet })_{6}\left(\mathrm{H}_{2} \mathrm{O}\right)_{4}\right]\left[\mathrm{Tf}_{2} \mathrm{~N}\right]_{6} \cdot{ }^{48,60}$

The crystal structure of $\left[\left(\mathrm{UO}_{2}\right)_{2}(\text { bet })_{6}\left(\mathrm{H}_{2} \mathrm{O}\right)_{2}\right]\left[\mathrm{Tf}_{2} \mathrm{~N}\right]_{4}$ consists of the binuclear complex cation $\left[\left(\mathrm{UO}_{2}\right)_{2}(\mathrm{bet})_{6}\right]^{4+}$ with six coordinating betaine zwitterions and two water molecules, surrounded by four non-coordinating bistriflimide $\left[\mathrm{Tf}_{2} \mathrm{~N}\right]^{-}$counterions (Fig. 1). Two of the carboxyl functionalised betaine zwitterions are $\mu_{2}$-bridging. The other four betaine zwitterions exhibit monodentate coordination to each of the two uranyl cations in the asymmetric unit. Four of the coordinating betaine ligands and one water molecule form slightly distorted pentagonal-bipyramidal oxygen coordination around each of the uranium(VI) atoms. ${ }^{60 a}$ Spectroscopic studies revealed that the uranyl complex was decomposed in aqueous solution, while in acetonitrile and in the IL $[\mathrm{Hbet}]\left[\mathrm{Tf}_{2} \mathrm{~N}\right]$, the carboxylate groups remained coordinated.

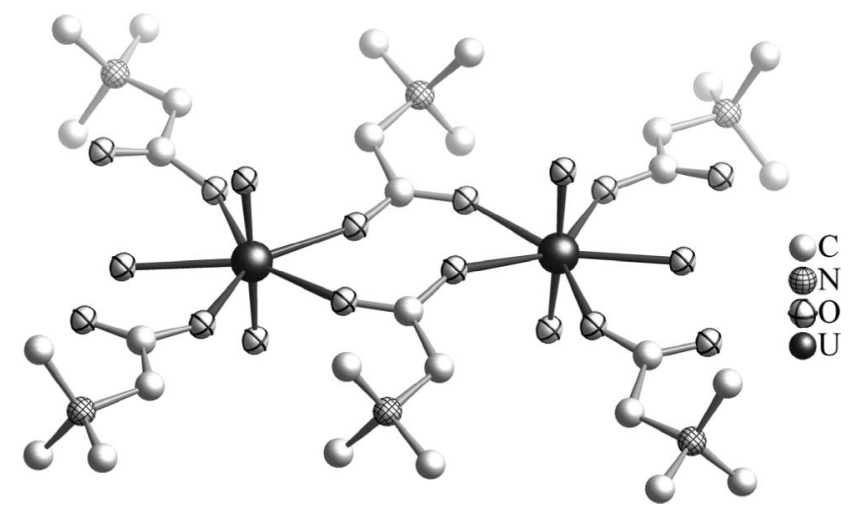

Fig. 1 The binuclear $\left[\left(\mathrm{UO}_{2}\right)_{2}(\text { bet })_{6}\left(\mathrm{H}_{2} \mathrm{O}\right)_{2}\right]^{4+}$ complex cation. Hydrogen atoms are omitted for clarity as in the following figures.

The structure of the $\left[\mathrm{Cu}_{2}(\text { betmIm })_{4}\left(\mathrm{H}_{2} \mathrm{O}\right)_{2}\right]\left[\mathrm{Tf}_{2} \mathrm{~N}\right]_{4} \cdot \mathrm{H}_{2} \mathrm{O}$ complex also exhibits a dimeric core, consisting of four $\mu_{2}$-bridging 
$N$-carboxymethyl- $N$-methylimidazolium ligands and two water molecules (Fig. 2). The surrounding anion network of four $\left[\mathrm{Tf}_{2} \mathrm{~N}\right]^{-}$ions prefer hydrogen bonding with the acidic protons of imidazolium cations rather than with the coordinated water molecules. Both copper(II) ions show a distorted square-pyramidal coordination by oxygen atoms. ${ }^{60 b}$

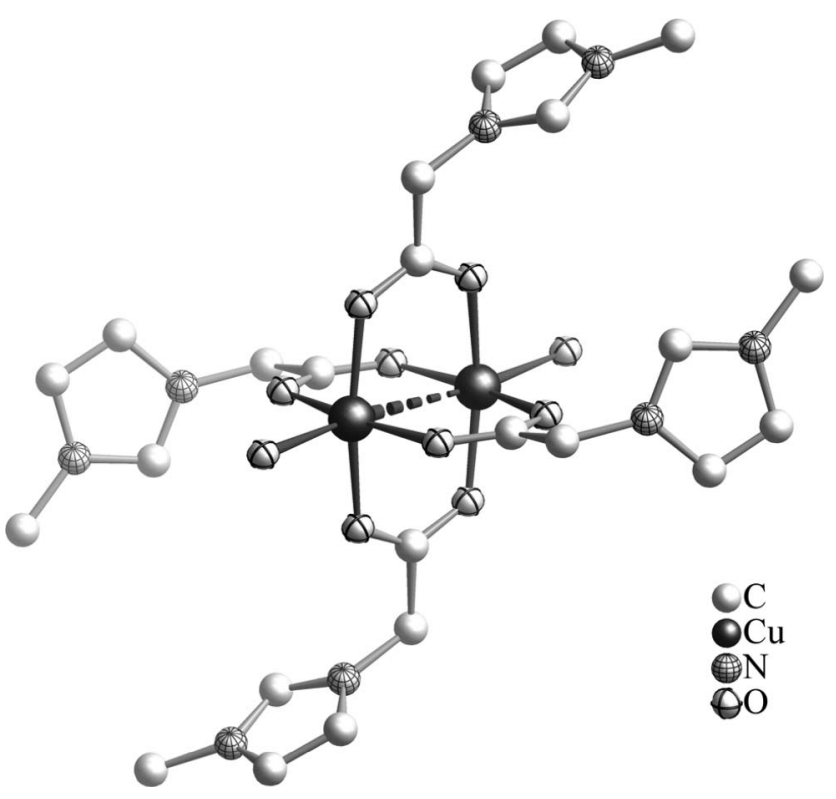

Fig. 2 The binuclear $\left[\mathrm{Cu}_{2}(\text { betmIm })_{4}\left(\mathrm{H}_{2} \mathrm{O}\right)_{2}\right]^{4+}$ complex cation.

Ruck et al. applied the Lewis-acidic IL $[\mathrm{BMIM}] \mathrm{Cl} / \mathrm{AlCl}_{3}$ to synthesise transition-metal clusters in high yields at room temperature. One example is the complex salt $\left[\mathrm{Mo}_{2} \mathrm{Te}_{12}\right] \mathrm{I}_{6},{ }^{51}$ which contains the heteropolycationic $\left[\mathrm{Mo}_{2} \mathrm{Te}_{12}\right]^{6+}$ cluster. $\left[\mathrm{Mo}_{2} \mathrm{Te}_{12}\right] \mathrm{I}_{6}$ was obtained by reacting $\mathrm{Mo}$, Te and $\mathrm{I}_{2}$ in $[\mathrm{BMIM}] \mathrm{Cl} / \mathrm{AlCl}_{3}$ at room temperature in only three days. This nicely demonstrates the versatility of IL in inorganic synthesis; the homeotypic $\left[\mathrm{Mo}_{2} \mathrm{Te}_{12}\right] \mathrm{Br}_{6}$ has been synthesised by Beck through chemical vapour transport (CVT) at about $300{ }^{\circ} \mathrm{C}$ within four weeks yielding less product. ${ }^{62}$ Moreover, the CVT synthesis of the iodide analogue failed completely. In the crystal structure of $\left[\mathrm{Mo}_{2} \mathrm{Te}_{12}\right] \mathrm{I}_{6}$, the cationic complexes $\left[\mathrm{Mo}_{2} \mathrm{Te}_{12}\right]^{6+}$ are surrounded by iodide ions, which connect them into a layer structure. In the complex cation $\left[\left(\mathrm{Mo}^{3+}\right)_{2}\left(\mathrm{Te}_{2}{ }^{2-}\right)_{2}\left(\mathrm{Te}_{4}{ }^{2+}\right)_{2}\right]^{6+}$, the two molybdenum atoms are connected by two bridging $\eta^{2}-\mathrm{Te}_{2}{ }^{2-}$ dumbbells (Fig. 3). In addition, each molybdenum atom is coordinated by a terminal $\mathrm{Te}_{4}{ }^{2+}$ polycation in $\eta^{4}$ mode. As a result, both molybdenum atoms are in square-antiprismatic environment. Despite the short Mo $\cdots$ Mo distance of $297 \mathrm{pm}$, a paramagnetic moment of $3.53 \mu_{\mathrm{B}}$ per molybdenum(III) atom was observed, which indicates that the magnetic moments are not coupled.

Raubenheimer et al. prepared several homonuclear and heteronuclear organometallic complexes employing IL as reagent and solvent as well, e.g., binuclear cobalt complexes, $\left[\{\mathrm{APIM}\} \mathrm{Co}_{2}(\mathrm{CO})_{6}\right] \mathrm{PF}_{6}$ and $\left[\{\mathrm{APIM}\} \mathrm{Co}_{2}(\mathrm{CO})_{6}\right] \mathrm{B}\left(\mathrm{C}_{6} \mathrm{H}_{5}\right)_{4}$ were synthesised by reacting $\mathrm{Co}_{2}(\mathrm{CO})_{8}$ with freshly prepared IL [APIM]X $\left(\mathrm{X}=\mathrm{PF}_{6}{ }^{-}, \mathrm{B}\left(\mathrm{C}_{6} \mathrm{H}_{5}\right)_{4}{ }^{-}\right)$in dichloromethane. The former complex represents first example of an organometallic IL. ${ }^{46 b}$

The structure of the binuclear cobalt complex $\left[\{\mathrm{APIM}\} \mathrm{Co}_{2}(\mathrm{CO})_{6}\right] \mathrm{PF}_{6}$ consists of a pseudo-tetrahedral $\mathrm{Co}_{2} \mathrm{C}_{2}$ -

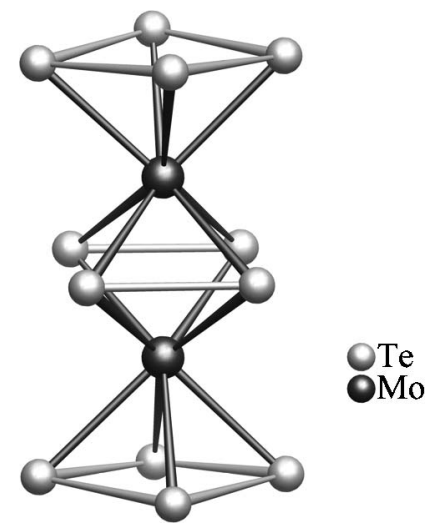

Fig. 3 The binuclear $\left[\mathrm{Mo}_{2} \mathrm{Te}_{12}\right]^{6+}$ complex cation.

core. The coordination of each cobalt atom is pseudo-octahedral, bridged by the alkyne ligand (Fig. 4). The imidazolium units are arranged in layers and face each other while the $\mathrm{Co}_{2}(\mathrm{CO})_{6}$ units face each other in the alternate layers.

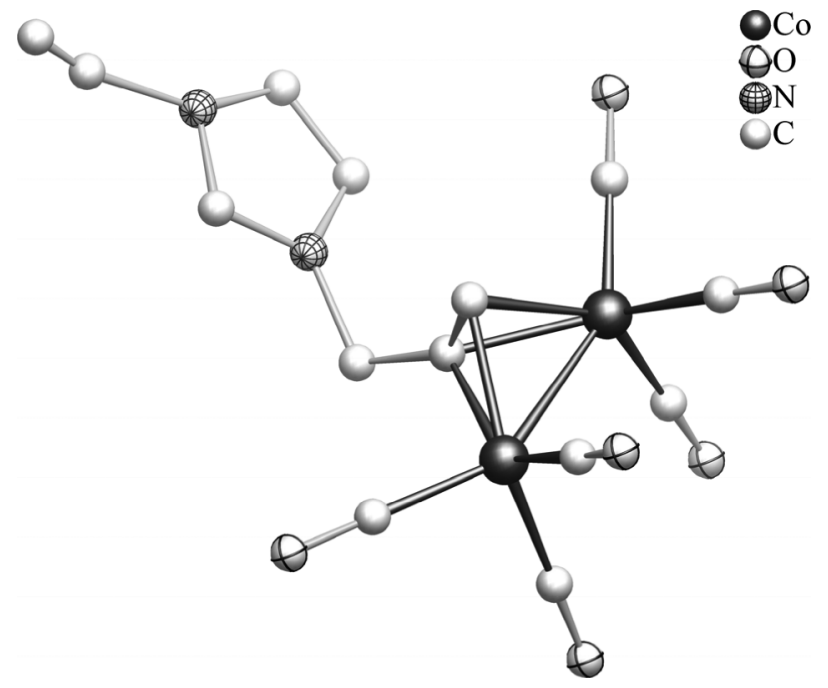

Fig. 4 The binuclear cobalt $\left[\{\mathrm{APIM}\} \mathrm{Co}_{2}(\mathrm{CO})_{6}\right]^{+}$complex cation.

Dyson and co-workers synthesised several IL based, versatile ruthenium precursors like binuclear organometallic complex $\left[\mathrm{RuCl}_{2}\left(\eta^{6} \text {-arene }\right)\right]_{2}$ for aqueous and ionic liquid biphasic catalysis. $^{47 c}$

Xia et al. prepared two organometallic heteronuclear complexes $[\mathrm{bmim}] \mathrm{K}\left[\mathrm{Co}(\mathrm{CO})_{4}\right]_{2}$ and $\left[\mathrm{C}_{4} \mathrm{Py}\right] \mathrm{K}\left[\mathrm{Co}(\mathrm{CO})_{4}\right]_{2}$ by reacting a tetrahydrofuran solution of $\mathrm{KCo}(\mathrm{CO})_{4}$ with $[\mathrm{bmim}] \mathrm{Br}$ or $\left[\mathrm{C}_{4} \mathrm{Py}\right] \mathrm{Br}$ dissolved in a minimum amount of methanol. ${ }^{46 d}$

The crystal structure of the heteronuclear complex $[\mathrm{bmim}] \mathrm{K}\left[\mathrm{Co}(\mathrm{CO})_{4}\right]_{2}$ shows two $\left[\mathrm{Co}(\mathrm{CO})_{4}\right]^{-}$units, connected through one potassium cation, and a bulky organic cation [bmim $]^{+}$ as the counterion (Fig. 5). The molecular structure is represented as discrete ion pairs, with little affinity between the cations and the anions.

Xiao et al. synthesised an organometallic binuclear complex $[\operatorname{PdBr}(\mu-\mathrm{Br})(\text { bmiy })]_{2}$ (bmiy = 1-butyl-3-methylimidazol-2-ylidene) by reacting $\mathrm{Pd}(\mathrm{OAc})_{2}$ and $[\mathrm{bmim}] \mathrm{Br}$ in tetrahydrofuran and demonstrated it as an efficient catalyst precursor. ${ }^{46 e}$ 


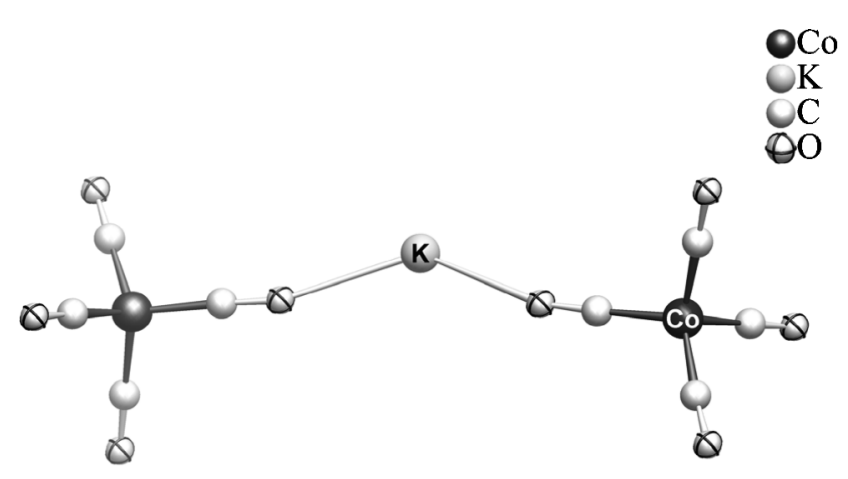

Fig. 5 The heteronuclear complex anion $\mathrm{K}\left[\mathrm{Co}(\mathrm{CO})_{4}\right]_{2}^{-}$.

Recently, Hagiwara et al. reported the binuclear molybdenum complex $[\mathrm{BPy}]_{2}\left[\mathrm{Mo}_{2} \mathrm{O}_{4} \mathrm{~F}_{6}\right]$. It was obtained in an attempt to crystallise the low-melting salt $\mathrm{BPyMoOF}_{5}$, but single crystals of $[\mathrm{BPy}]_{2}\left[\mathrm{Mo}_{2} \mathrm{O}_{4} \mathrm{~F}_{6}\right]$ resulted from the hydrolysis of $\mathrm{BPyMoOF}_{5}$ with some traces of water during the crystal growth. ${ }^{63}$

\section{Trinuclear complexes}

Saito et al. synthesised a trinuclear rhenium sulfide cluster from Lewis basic IL by treating $\mathrm{Re}_{3} \mathrm{~S}_{7} \mathrm{Cl}_{7}$ with a $1: 1$ mixture of EMIMBr and $\mathrm{AlBr}_{3}$ at $70{ }^{\circ} \mathrm{C}$ for 2 days followed by refluxing in acetonitrile to get a viscous solution. After cooling and filtration, diethyl ether was layered and a black solid was obtained, which was recrystallised from acetonitrile-diethyl ether to obtain good quality single-crystals of $\operatorname{Im}_{3}\left[\operatorname{Re}_{3}\left(\mu_{3}-\mathrm{S}\right)(\mu-\mathrm{S})_{3} \mathrm{Br}_{9}\right] \mathrm{Br}$. The structure of the cluster anion comprises an almost equilateral triangle of rhenium atoms with one $\mu_{3}-S^{2-}$, three $\mu-S^{2-}$ and nine terminal $\mathrm{Br}^{-}$ligands (Fig. 6). The cation network is composed of three EMIM $^{+}$ions. This synthetic procedure has revealed that the IL EMIMBr/ $\mathrm{AlBr}_{3}$ has the ability to remove one of the $\mathrm{S}$ atoms in the $\mu-\mathrm{S}_{2}{ }^{2-}$ ligands of the precursor complex $\left[\mathrm{Re}_{3}\left(\mu_{3}-\mathrm{S}\right)\left(\mu-\mathrm{S}_{2}\right)_{3} \mathrm{Cl}_{6}\right] \mathrm{Cl}$, to exchange $\mathrm{Cl}^{-}$for $\mathrm{Br}^{-}$, and to coordinate extra bromido ligands to the $\mathrm{Re}_{3} \mathrm{~S}_{4}$ core. $^{45}$

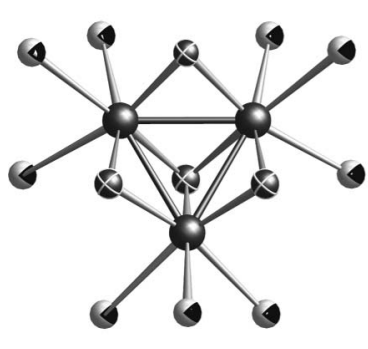

a
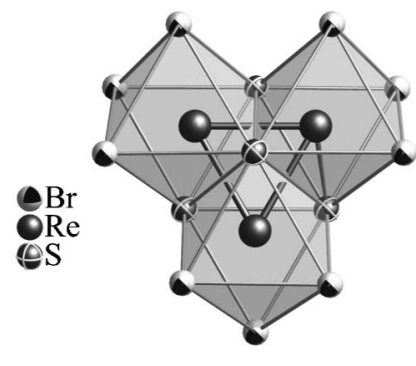

b
Fig. 6 (a) The $\left[\operatorname{Re}_{3}\left(\mu_{3}-S\right)(\mu-S)_{3} \mathrm{Br}_{9}\right]^{2-}$ cluster anion; (b) polyhedra representation emphasising the edge-sharing of coordination octahedra.

Nockemann and co-workers demonstrated the preparation of the trinuclear cobalt complex $\left[\mathrm{Co}_{3}(\text { bet })_{8}(\mathrm{Hbet})_{2}\left(\mathrm{H}_{2} \mathrm{O}\right)_{2}\right]-$ $\left[\mathrm{Tf}_{2} \mathrm{~N}\right]_{10}[\text { Hbet }]_{2}$ from the task-specific IL $[$ Hbet $]\left[\mathrm{Tf}_{2} \mathrm{~N}\right]^{48 a}$ The synthesis was accomplished by reacting $\mathrm{Co}(\mathrm{OH})_{2}$ with [Hbet] $\left[\mathrm{Tf}_{2} \mathrm{~N}\right]$ in the presence of water. The crystal structure of $\left[\mathrm{Co}_{3}(\text { bet })_{8}(\mathrm{Hbet})_{2}\left(\mathrm{H}_{2} \mathrm{O}\right)_{2}\right]\left[\mathrm{Tf}_{2} \mathrm{~N}\right]_{10}[\mathrm{Hbet}]_{2}$ contains discrete trimeric $\left[\mathrm{Co}_{3}(\text { bet })_{8}(\mathrm{Hbet})_{2}\left(\mathrm{H}_{2} \mathrm{O}\right)_{2}\right]^{8+}$ units, eight non-coordinating $\left[\mathrm{Tf}_{2} \mathrm{~N}\right]^{-}$ anions as counter ions and two additional [Hbet][ $\left.\mathrm{Tf}_{2} \mathrm{~N}\right]$ ion pairs as "solvent" molecules in the crystal structure. The three cobalt(II) atoms of the trimeric $\left[\mathrm{Co}_{3}(\mathrm{bet})_{8}(\mathrm{Hbet})_{2}\left(\mathrm{H}_{2} \mathrm{O}\right)_{2}\right]^{8+}$ units are connected by four $\mu_{2}$-bridging carboxylate groups of the betaine ligands and two bridging water molecules. The octahedral oxygen coordination of each cobalt atom is slightly distorted (Fig. 7).

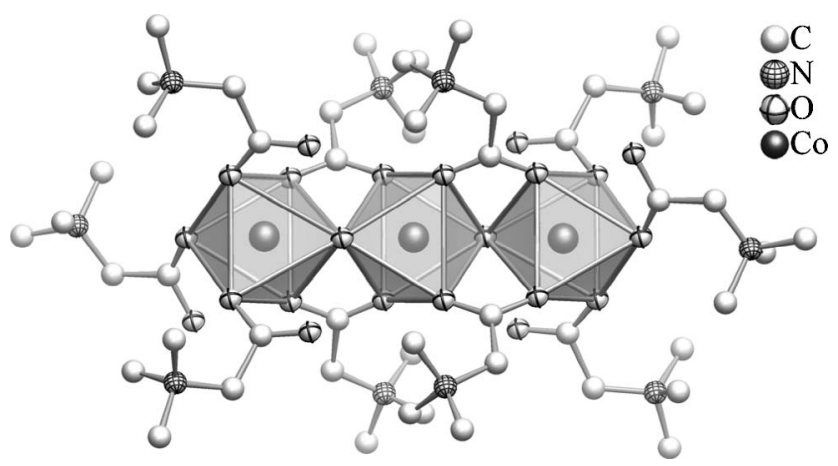

Fig. 7 The trimeric $\left[\mathrm{Co}_{3}(\text { bet })_{8}(\mathrm{Hbet})_{2}\left(\mathrm{H}_{2} \mathrm{O}\right)_{2}\right]^{8+}$ complex cation, highlighting the corner-sharing $\left[\mathrm{CoO}_{6}\right]$ octahedra.

A trinuclear tungsten cluster compound was synthesised by Ruck et al. using a Lewis acidic IL as reaction medium. Dark brown, column-like crystals of $\mathrm{Sn}[\mathrm{SnCl}]\left[\mathrm{W}_{3} \mathrm{Cl}_{13}\right]$ were obtained at room temperature by the reduction of $\mathrm{WCl}_{6}$ with elemental tin in $[\mathrm{BMIM}] \mathrm{Cl} / \mathrm{AlCl}_{3} .{ }^{50}$ The structure of $\mathrm{Sn}[\mathrm{SnCl}]\left[\mathrm{W}_{3} \mathrm{Cl}_{13}\right]$ contains a trinuclear $\left[\mathrm{W}_{3} \mathrm{Cl}_{13}\right]^{3-}$ cluster anion, a tin(II) cation, and a $[\mathrm{SnCl}]^{+}$ cation. The cluster anion $\left[\mathrm{W}_{3} \mathrm{Cl}_{13}\right]^{3-}$ comprises an equilateral triangle of tungsten atoms, which are connected by one $\mu_{3}-\mathrm{Cl}$ and three $\mu-\mathrm{Cl}$ ligands. Each tungsten atom is further coordinated by three terminal $\mathrm{Cl}^{-}$ions. Therefore, all tungsten atoms are found in slightly distorted octahedral environment (Fig. 8). The tin(II) cations, which are in trigonal-pyramidal and in distorted trigonalantiprismatic coordination by terminal chloride ions, connect the clusters into a layer structure. Similar cluster compounds, $\mathrm{A}_{3}\left[\mathrm{~W}_{3} \mathrm{Cl}_{13}\right]$ with $\mathrm{A}=\mathrm{Li}, \mathrm{Na}$ or $\mathrm{K}$, have been obtained previously by Messerle et al. and Meyer et al. applying classical solid-state synthesis, which necessitated 240 to $500{ }^{\circ} \mathrm{C}$ and 6 to 7 days. ${ }^{64,65}$
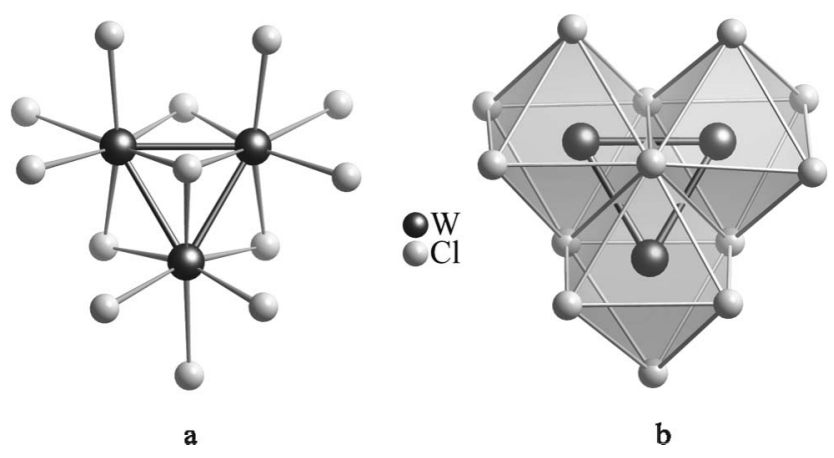

Fig. 8 (a) The trinuclear $\left[\mathrm{W}_{3}\left(\mu_{3}-\mathrm{Cl}\right)(\mu-\mathrm{Cl})_{3} \mathrm{Cl}_{9}\right]^{3-}$ cluster anion; (b) polyhedra representation emphasising the edge-sharing of coordination octahedra.

Raubenheimer et al. prepared a heterotrinuclear gold ferrocenyl complex bis $\{1-[(E)$-2-butenyl]-3-(4-ferrocenylphenyl)-2 $H$ imidazol-2-ylidene $\}$ gold(I) tetrafluoroborate by the reaction of a freshly prepared mononuclear complex 1-[(E)-2-butenyl]-3-(4ferrocenylphenyl)imidazolium tetrafluoroborate with $\mathrm{Ag}_{2} \mathrm{O}$, and 
tetraethylammonium chloride in a mixture of $\mathrm{CH}_{2} \mathrm{Cl}_{2}$ and $\mathrm{MeOH}$, followed by the addition of chlorido(dimethylsulfide)gold(I). ${ }^{46 c}$

The asymmetric unit in the heteronuclear compound contains the gold complex, a highly disordered $\mathrm{BF}_{4}{ }^{-}$anion, and a solvent molecule, $\mathrm{CH}_{2} \mathrm{Cl}_{2}$. The structure reveals a linear coordination of the central gold(I) atom to the two carbene carbons. The cyclopentadienyl rings are almost parallel. The $\eta^{5}-\mathrm{C}_{5} \mathrm{H}_{4}$ rings and the phenyl rings are nearly parallel (Fig. 9).

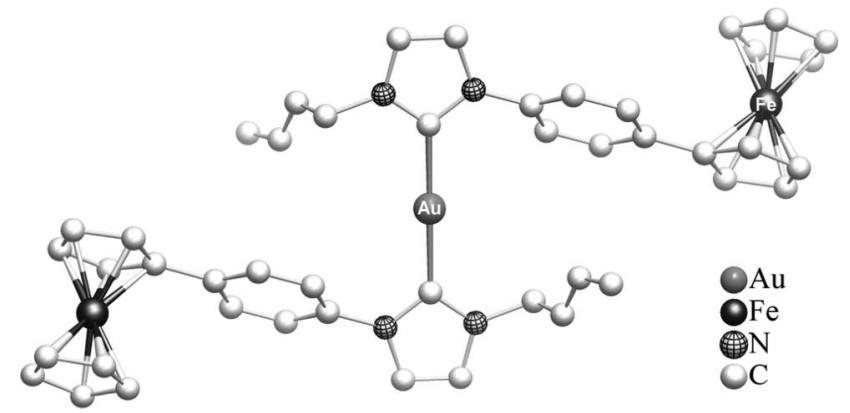

Fig. 9 The trinuclear bis $\{1-[(E)-2-$ butenyl $]-3-(4-f e r r o c e n y l p h e n y l)-2 H$ imidazol-2-ylidene $\}$ gold(I) complex cation.

\section{Tetranuclear complexes}

The first tetranuclear cobalt complex $\left[\{\right.$ DPIM $\left.\}\left\{\mathrm{Co}_{2}(\mathrm{CO})_{6}\right\}_{2}\right] \mathrm{BPh}_{4}$ was reported by Dyson and co-workers. ${ }^{66}$ The synthesis was performed, employing 1,3-dialkyne-functionalised imidazolium IL derivatives, e.g. 1,3-dipentynylimidazolium tetraphenylborate, was treated with $\mathrm{Co}_{2}(\mathrm{CO})_{8}$ in dichloromethane. In the structure of the tetranuclear complex, the 1,3-dialkyne arms adopt a trans conformation. The $\mathrm{Co}-\mathrm{Co}$ distances are found to be shorter than in the parent $\mathrm{Co}_{2}(\mathrm{CO})_{8}$ complex. The cobalt atoms are bridged by alkyne ligands (Fig. 10) and three different $\mathrm{C}-\mathrm{H} \cdots \pi$ interactions were observed in the structure. In addition, one of the $\mathrm{H}$ atoms in the $\mathrm{CH}_{2}$ group is also involved in a $\mathrm{C}-\mathrm{H} \cdots \pi$ interactions with the phenyl ring of the counterion.

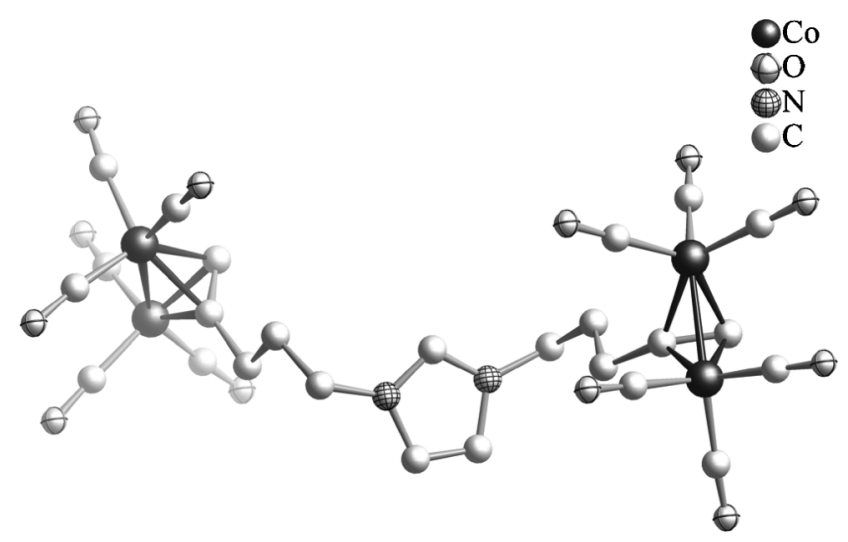

Fig. 10 The tetranuclear $\left[\{\mathrm{DPIM}\}\left\{\mathrm{Co}_{2}(\mathrm{CO})_{6}\right\}_{2}\right]^{+}$complex cation.

Nockemann et al. synthesised two tetranuclear complexes, $\left[\mathrm{Mn}_{4}(\text { bet })_{10}\left(\mathrm{H}_{2} \mathrm{O}\right)_{4}\right]\left[\mathrm{Tf}_{2} \mathrm{~N}\right]_{8}$ and $\left[\mathrm{Zn}_{4}(\text { bet })_{10}\left(\mathrm{H}_{2} \mathrm{O}\right)_{2}\right]\left[\mathrm{Tf}_{2} \mathrm{~N}\right]_{8}$, by applying the task-specific IL [Hbet][Tf $\left.{ }_{2} \mathrm{~N}\right]{ }^{48 a}$ The synthesis was performed by reacting the corresponding metal oxides with $\left[\mathrm{Hbet}\left[\mathrm{Tf}_{2} \mathrm{~N}\right]\right.$ in the presence of water. The crystal structure of the tetranuclear manganese complex $\left[\mathrm{Mn}_{4}\left(\right.\right.$ bet $\left._{10}\left(\mathrm{H}_{2} \mathrm{O}\right)_{4}\right]\left[\mathrm{Tf}_{2} \mathrm{~N}\right]_{8}$ consists of discrete tetrameric $\left[\mathrm{Mn}_{4}(\text { bet })_{10}\left(\mathrm{H}_{2} \mathrm{O}\right)_{4}\left(\mathrm{Tf}_{2} \mathrm{~N}\right)\right]^{7+}$ units and seven non-coordinating $\left[\mathrm{Tf}_{2} \mathrm{~N}\right]^{-}$counterions (Fig. 11). The four manganese(II) atoms, which differ in their coordination, are connected by bridging carboxylate groups of the betaine ligands. The oxygen coordination environment of the manganese atoms Mn2 and Mn4 can be described as strongly distorted octahedra, while Mn1 and Mn3 are found in distorted squarebased pyramidal coordination by five oxygen atoms. In addition to the bridging carboxylate groups of the ligands, water molecules complete the octahedral surrounding of Mn2 and Mn4.

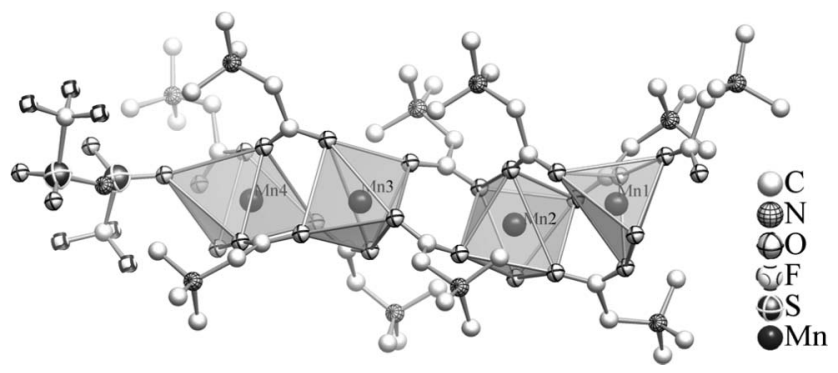

Fig. 11 The tetranuclear $\left[\mathrm{Mn}_{4}(\text { bet })_{10}\left(\mathrm{H}_{2} \mathrm{O}\right)_{4}\left(\mathrm{Tf}_{2} \mathrm{~N}\right)\right]^{7+}$ complex cation.

In the tetrameric zinc complex $\left[\mathrm{Zn}_{4}(\text { bet })_{10}\left(\mathrm{H}_{2} \mathrm{O}\right)_{2}\right]\left[\mathrm{Tf}_{2} \mathrm{~N}\right]_{8}$, the discrete tetrameric cation $\left[\mathrm{Zn}_{4}(\mathrm{bet})_{10}\left(\mathrm{H}_{2} \mathrm{O}\right)_{2}\right]^{8+}$ is surrounded by eight non-coordinating $\left[\mathrm{Tf}_{2} \mathrm{~N}\right]^{-}$anions (Fig. 12). The zinc(II) atoms are connected by bridging carboxylate groups of the betaine ligands. The crystal structure shows two independent zinc ( $\mathrm{Zn} 1$ and $\mathrm{Zn} 2$ ) atoms which exhibit square-pyramidal coordination. $\mathrm{Zn} 1$ is coordinated by five carboxylate groups that are in $\mu$ bridging to the adjacent zinc atoms $\mathrm{Zn} 2$ and $\mathrm{Zn} 1^{\prime}$, respectively. $\mathrm{Zn} 2$ is surrounded by one monodentate betaine ligand, three betaine ligands that are $\mu$-bridging to $\mathrm{Zn} 1$ and one water molecule.

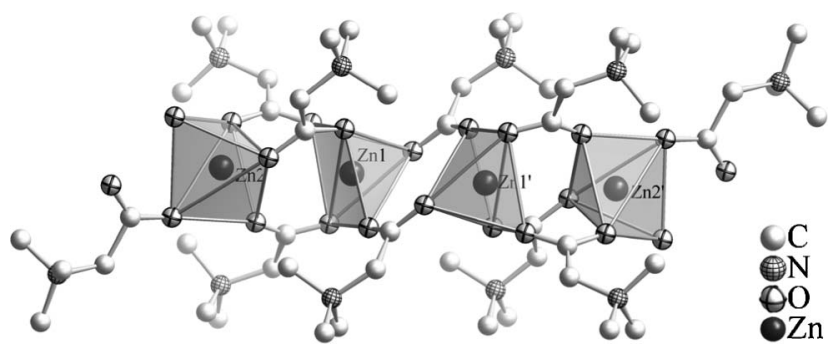

Fig. 12 The tetranuclear $\left[\mathrm{Zn}_{4}(\text { bet })_{10}\left(\mathrm{H}_{2} \mathrm{O}\right)_{2}\right]^{8+}$ complex cation.

\section{Pentanuclear complexes}

Nockemann and co-workers continued their efforts to build even higher nuclearity metal complexes and were successful in isolating two pentanuclear complexes, $\left[\mathrm{Ni}_{5}(\text { bet })_{12}\left(\mathrm{H}_{2} \mathrm{O}\right)_{6}\right]\left[\mathrm{Tf}_{2} \mathrm{~N}\right]_{10}$ and $\left[\left(\mathrm{Pb}_{4} \mathrm{O}\right) \mathrm{Pb}(\mathrm{OH})(\text { bet })_{8}\left(\mathrm{Tf}_{2} \mathrm{~N}\right)_{3}\right]\left[\mathrm{Tf}_{2} \mathrm{~N}\right]_{4} \cdot \mathrm{MeOH}$, by applying the same synthetic strategy of reacting metal oxides with $[\mathrm{Hbet}]\left[\mathrm{Tf}_{2} \mathrm{~N}\right]$ in the presence of water or methanol. ${ }^{48 a}$

The crystal structure of the pentanuclear complex $\left[\mathrm{Ni}_{5}(\text { bet })_{12}\left(\mathrm{H}_{2} \mathrm{O}\right)_{6}\right]\left[\mathrm{Tf}_{2} \mathrm{~N}\right]_{10}$ consists of discrete pentameric $\left[\mathrm{Ni}_{5}(\text { bet })_{12}\left(\mathrm{H}_{2} \mathrm{O}\right)_{6}\right]^{10+}$ units and non-coordinating $\left[\mathrm{Tf}_{2} \mathrm{~N}\right]^{-}$anions as counterions. The three symmetrically independent nickel(II) atoms of the pentameric $\left[\mathrm{Ni}_{5}(\text { bet })_{12}\left(\mathrm{H}_{2} \mathrm{O}\right)_{6}\right]^{10+}$ unit are connected by eight $\mu_{2}$-bridging carboxylate groups of the betaine ligands and four bridging water molecules. Each $\mathrm{Ni}$ atom is coordinated 
by oxygen atoms of four betaine ligands and two water molecules to give slightly distorted octahedral coordination polyhedron. The terminal betaine ligands and water molecules are coordinated to $\mathrm{Nil}$ atoms in a monodentate fashion (Fig. 13).

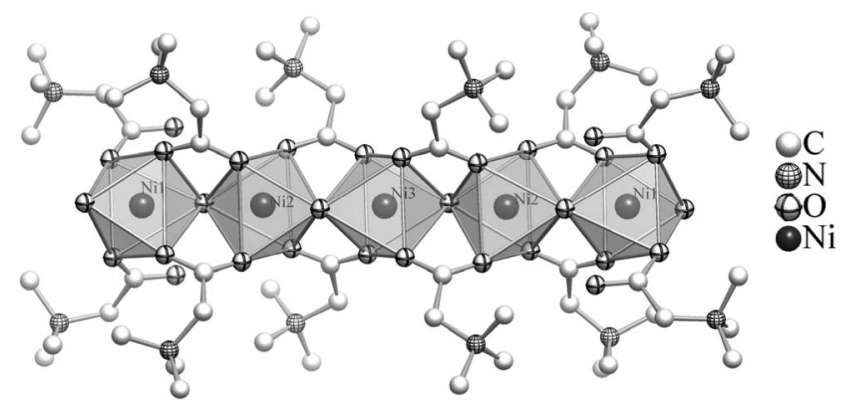

Fig. 13 The pentanuclear $\left[\mathrm{Ni}_{5}(\text { bet })_{12}\left(\mathrm{H}_{2} \mathrm{O}\right)_{6}\right]^{10+}$ complex cation, the chain of corner-sharing $\left[\mathrm{NiO}_{6}\right]$ octahedra is prominent.

The pentanuclear lead complex $\left[\left(\mathrm{Pb}_{4} \mathrm{O}\right) \mathrm{Pb}(\mathrm{OH})(\text { bet })_{8}\left(\mathrm{Tf}_{2} \mathrm{~N}\right)_{3}\right]-$ $\left[\mathrm{Tf}_{2} \mathrm{~N}\right]_{4} \cdot \mathrm{MeOH}$ contains an oxo-hydroxo cluster inside the discrete pentameric $\left[\left(\mathrm{Pb}_{4} \mathrm{O}\right) \mathrm{Pb}(\mathrm{OH})(\text { bet })_{8}\left(\mathrm{Tf}_{2} \mathrm{~N}\right)_{3}\right]^{4+}$ unit. The cation is surrounded by four non-coordinating $\left[\mathrm{Tf}_{2} \mathrm{~N}\right]^{-}$ counter ions and one methanol molecule. The cationic unit $\left[\left(\mathrm{Pb}_{4} \mathrm{O}\right) \mathrm{Pb}(\mathrm{OH})(\text { bet })_{8}\left(\mathrm{Tf}_{2} \mathrm{~N}\right)_{3}\right]^{4+}$ is composed of an oxo-centred $\left[\mathrm{OPb}_{4}\right]^{6+}$ tetrahedron, which is connected to an additional lead atom through a $\mu_{3}$-bridging hydroxide and chelating-bridging carboxylate groups of betaine ligands. The $\left[\mathrm{Pb}_{4}\left(\mu_{4}-\mathrm{O}\right) \mathrm{Pb}\left(\mu_{3}-\right.\right.$ $\mathrm{OH})]^{7+}$ moiety is surrounded by eight betaine ligands and two coordinating $\left[\mathrm{Tf}_{2} \mathrm{~N}\right]^{-}$anions (Fig. 14). The $\mu_{4}-\mathrm{O}$ atom tetrahedrally bridges $\mathrm{Pb} 2, \mathrm{~Pb} 3, \mathrm{~Pb} 4$ and $\mathrm{Pb} 5$ atoms while the $\left(\mu_{3}-\mathrm{OH}\right)$-ligand bridges $\mathrm{Pb} 1, \mathrm{~Pb} 2$ and $\mathrm{Pb} 3$ in a pyramidal shape (Fig. 14).

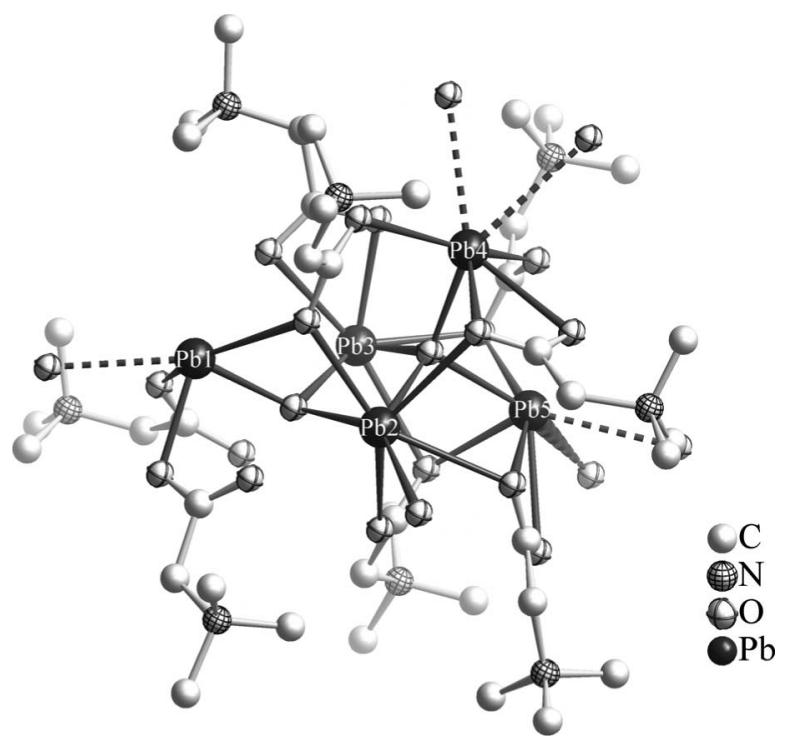

Fig. 14 The pentanuclear $\left[\left(\mathrm{Pb}_{4} \mathrm{O}\right) \mathrm{Pb}(\mathrm{OH})(\text { bet })_{8}\left(\mathrm{Tf}_{2} \mathrm{~N}\right)_{3}\right]^{4+}$ complex cation.

Ruck et al. synthesised a pentanuclear molybdenum cluster compound $\mathrm{Bi}\left[\mathrm{Mo}_{5} \mathrm{Cl}_{13}\right] \mathrm{Cl}$ by the reduction of $\mathrm{MoCl}_{5}$ with elemental bismuth in Lewis-acidic [BMIM]Cl/ $\mathrm{AlCl}_{3}$ at room temperature. ${ }^{52,53}$ The resulting bismuth(III) cations are included in the product.

The crystal structure of $\mathrm{Bi}\left[\mathrm{Mo}_{5} \mathrm{Cl}_{13}\right] \mathrm{Cl}$ is a defect variant of the $\mathrm{Pb}\left[\mathrm{Mo}_{6} \mathrm{Cl}_{14}\right]$ type. ${ }^{67}$ One of the molybdenum atoms of the $\mathrm{Mo}_{6}$ cluster core is missing, resulting in a $\left[\mathrm{Mo}_{5} \mathrm{Cl}_{13}\right]^{2-}$ cluster and a chloride ion that is not bonded to the cluster. In the $\left[\mathrm{Mo}_{5} \mathrm{Cl}_{13}\right]^{2-}$ cluster anion, the molybdenum atoms form a square pyramid, where each metal atom is coordinated by four $\mathrm{Cl}^{\mathrm{i}}$ ligands and one $\mathrm{Cl}^{\mathrm{a}}$ ligand $\left({ }^{\mathrm{i}}=\right.$ inner, ${ }^{\mathrm{a}}=$ apical or outer, according to the notation of Schäfer and Schnering ${ }^{68}$ ). As a result, the $\mathrm{Mo}_{5}$ core is surrounded by eight inner $\mathrm{Cl}^{\mathrm{i}}$ ligands in the form of a cube. Out of these eight inner $\mathrm{Cl}^{\mathrm{i}}$, four are present as $\mu_{3}$-bridging ligands above the faces of the pyramid and the other four as $\mu$-bridging ligands to the basal Mo atoms. The bismuth cations are surrounded by the five apical $\mathrm{Cl}^{\mathrm{a}}$ and the non-cluster-bonded chloride ion in a slightly distorted octahedral environment (Fig. 15). $\mathrm{Bi}\left[\mathrm{Mo}_{5} \mathrm{Cl}_{13}\right] \mathrm{Cl}$ is paramagnetic with an effective magnetic moment of $1.67 \mu_{\mathrm{B}}$, which indicates an unpaired electron in the $\left[\mathrm{Mo}_{5} \mathrm{Cl}_{13}\right]^{2-}$ anion corresponding to the odd number of 19 electrons in cluster core.

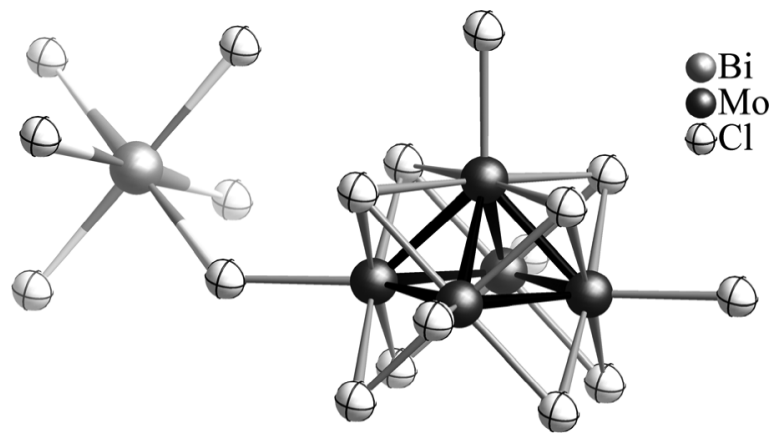

Fig. $15 \mathrm{~A}$ characteristic unit of the structure of $\mathrm{Bi}\left[\mathrm{Mo}_{5} \mathrm{Cl}_{13}\right] \mathrm{Cl}$, where each molybdenum atom is coordinated by four inner $\mathrm{Cl}^{\mathrm{i}}$ and one apical $\mathrm{Cl}^{\mathrm{a}}$ and bismuth is in octahedral surrounding.

\section{Hexanuclear and high-nuclearity complexes}

Hughbanks and co-workers introduced a new synthetic scheme, using room-temperature Lewis-basic IL to isolate centred hexanuclear zirconium halogenide cluster compounds and studied their spectroscopic, electrochemical, and structural properties. ${ }^{40-43}$ Room-temperature chloridoaluminate molten salts, mixtures of $\mathrm{EMImCl} / \mathrm{AlCl}_{3}$ were used as solvents to excise and isolate centred hexanuclear zirconium halogenide clusters from their solid-state precursors, e.g. $\mathrm{Zr}_{6} \mathrm{Br}_{14} \mathrm{Fe}, \mathrm{Li}_{2} \mathrm{Zr}_{6} \mathrm{Cl}_{15} \mathrm{Mn}$, or $\mathrm{Rb}_{5} \mathrm{Zr}_{6} \mathrm{Cl}_{18} \mathrm{~B}$. Compounds that include the cation of the IL, such as $\operatorname{Im}_{5}\left[\left(\mathrm{Zr}_{6} \mathrm{Mn}\right) \mathrm{Cl}_{18}\right] \cdot 1.5 \mathrm{CH}_{3} \mathrm{CN}, \quad \operatorname{Im}_{4}\left[\left(\mathrm{Zr}_{6} \mathrm{C}\right) \mathrm{Cl}_{18}\right]$, $\operatorname{Im}_{4}\left[\left(\mathrm{Zr}_{6} \mathrm{Fe}\right) \mathrm{Cl}_{18}\right], \quad \operatorname{Im}_{5}\left[\left(\mathrm{Zr}_{6} \mathrm{Mn}\right) \mathrm{Cl}_{18}\right] \cdot \mathrm{C}_{6} \mathrm{H}_{5} \mathrm{CH}_{3} \cdot 2 \mathrm{CH}_{3} \mathrm{CN}$ or $\mathrm{Im}_{5}\left[\left(\mathrm{Zr}_{6} \mathrm{~B}\right) \mathrm{Cl}_{18}\right] \cdot \mathrm{C}_{6} \mathrm{H}_{5} \mathrm{CH}_{3} \cdot 2 \mathrm{CH}_{3} \mathrm{CN}$, were isolated in good yield.

The molecular cluster anions consist of octahedral $\left(\mathrm{Zr}_{6} \mathrm{Z}\right)(\mathrm{Z}=$ $\mathrm{Fe}, \mathrm{Mn}, \mathrm{B}$ or C) units with the 12 edges bridged by inner chloride ligands. Six terminal (outer) chloride ions occupy the apical positions (Fig. 16). ${ }^{68}$

It was assumed that in basic molten salts, the chloride nucleophilicity is sufficient, which could serve as a reagent for excising these centred clusters from highly cross-linked solid-state compounds. They were also successful to carry out exchange of halogenides in the basic molten salts. This approach was found 


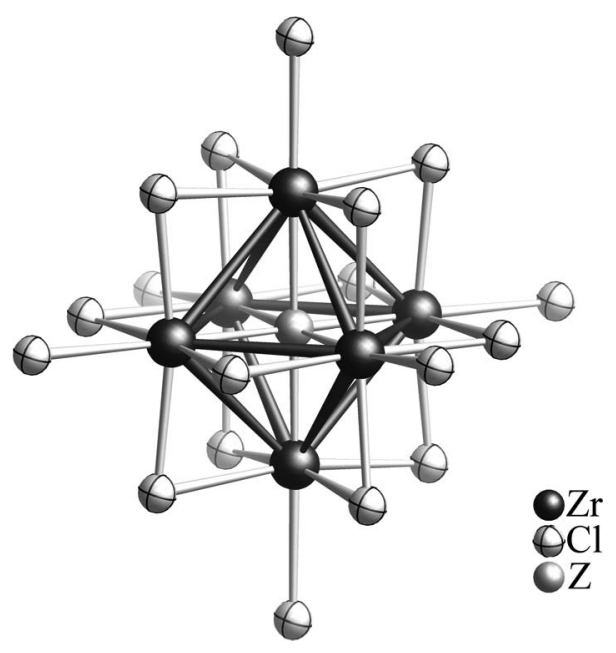

Fig. 16 A typical heptanuclear cluster anion $\left[\left(\mathrm{Zr}_{6} \mathrm{Z}\right) \mathrm{Cl}_{18}\right]^{n-}(\mathrm{Z}=\mathrm{Fe}, \mathrm{Mn}$, Be or B and $n=4$ or 5).

to be effective for several compounds that resist dissolution in acetonitrile or are unstable in aqueous solution. Later, Köckerling et al. followed the same route and isolated cluster phases $(\mathrm{EMIm})_{4}\left[\left(\mathrm{Zr}_{6} \mathrm{Fe}\right) \mathrm{Br}_{18}\right]$ and $(\mathrm{EMIm})_{4}\left[\left(\mathrm{Zr}_{6} \mathrm{Be}\right) \mathrm{Br}_{18}\right]$ from their solidstate precursors $\mathrm{Na}_{4}\left[\left(\mathrm{Zr}_{6} \mathrm{Be}\right) \mathrm{Cl}_{16}\right]$ and $\mathrm{K}\left[\left(\mathrm{Zr}_{6} \mathrm{Fe}\right) \mathrm{Cl}_{15}\right]$ by dissolving in Lewis-basic EMIMBr/AlBr . In the bromide-based IL, a complete exchange of all the outer and inner chlorides by bromide took place. ${ }^{44}$

A hexanuclear molybdenum cluster compound $\mathrm{BiCl}\left[\mathrm{Mo}_{6} \mathrm{Cl}_{14}\right]$ was prepared by Ruck and co-workers by reacting bismuth and $\mathrm{MoCl}_{5}$ in Lewis acidic [BMIM]Cl/ $\mathrm{AlCl}_{3}$ at room temperature. ${ }^{53}$ The crystal structure, which shows no noteworthy difference to the compound previously synthesised by a high-temperature method, ${ }^{22 c}$ consists of $\left[\mathrm{Mo}_{6} \mathrm{Cl}_{8}{ }^{\mathrm{i}} \mathrm{Cl}_{6}{ }^{\mathrm{a}}\right]^{2-}$ units containing an almost regular octahedral $\mathrm{Mo}_{6}$ cluster core. The clusters are bonded via $\mathrm{Cl}^{\mathrm{a}}$ to $[\mathrm{BiCl}]^{2+}$ dumbbells (Fig. 17).

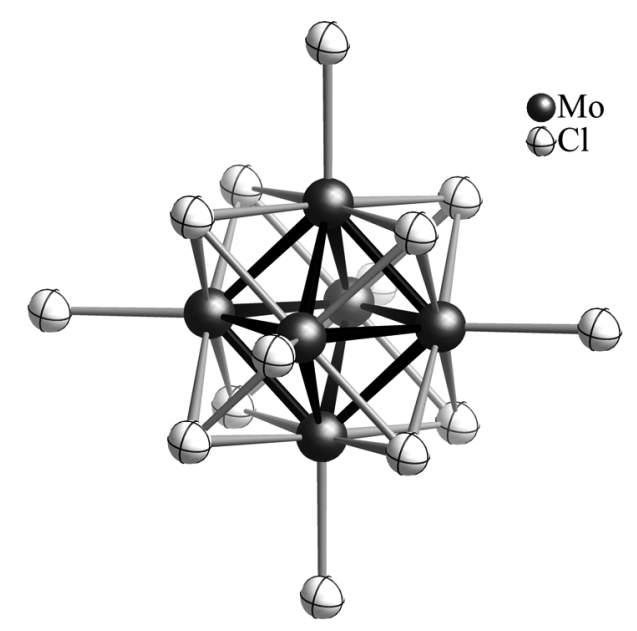

Fig. 17 The hexanuclear $\left[\mathrm{Mo}_{6} \mathrm{Cl}_{14}\right]^{2-}$ cluster anion.

Mudring and co-workers isolated a number of new salt-like structures from IL, containing lanthanides in the anion network. Besides mononuclear complexes, ${ }^{8-10}$ they also synthesised an octanuclear europium cluster compound $[\mathrm{bmpyr}]_{6}\left[\mathrm{Eu}_{8}\left(\mu_{4}-\mathrm{O}\right)\left(\mu_{3}-\right.\right.$ $\left.\mathrm{OH})_{12}\left(\mu_{2}-\mathrm{OTf}\right)_{14}(\mu-\mathrm{OTf})_{2}\right] \cdot 1.5$ HOTf from the IL [bmpyr][OTf].
The structural characterisation revealed an $\mathrm{Eu}_{8}$ cluster unit, which is centred by an oxide anion. ${ }^{11}$ Moreover, they also prepared some low-melting IL, e.g. $\left[\mathrm{C}_{3} \operatorname{mim}\right]\left[\operatorname{Eu}\left(\mathrm{Tf}_{2} \mathrm{~N}\right)_{4}\right]\left(\mathrm{mp}=81.0^{\circ} \mathrm{C}\right)$, $\left[\mathrm{C}_{4} \mathrm{mim}\right]\left[\mathrm{Eu}\left(\mathrm{Tf}_{2} \mathrm{~N}\right)_{4}\right]\left(\mathrm{mp}=67.9{ }^{\circ} \mathrm{C}\right)$, and $\left[\mathrm{C}_{4} \mathrm{mpyr}\right]_{2}\left[\operatorname{Eu}\left(\mathrm{Tf}_{2} \mathrm{~N}\right)_{5}\right]$ $\left(\mathrm{mp}=92.1^{\circ} \mathrm{C}\right)$. The dimeric europium units of the composition $\left[\mathrm{Eu}_{2}\left(\mathrm{Tf}_{2} \mathrm{~N}\right)_{8}\right]^{2-}$ were confirmed in the first two substances through crystallographic studies. These low-melting IL possess excellent photophysical properties (high lifetimes at high europium(III) concentration, small linewidth, and high colour purity), which might render them particularly valuable for various optical applications. ${ }^{9 a}$

\section{Coordination polymers}

Recently, Morris and co-workers introduced the concept of ionothermal synthesis, the use of an IL as solvent and potential template or structure directing agent in the preparation of crystalline solids, which offers several advantages over conventional hydrothermal and solvothermal materials synthesis methods. ${ }^{69}$ This new strategy was further conveniently exercised by $\mathrm{Yu}$ et al., Zhai et al., Bu et al., and many others to synthesise metal organic frameworks or coordination polymers. ${ }^{69-73}$

Morris and co-workers demonstrated that the homochiral frameworks SIMOF-1 (BMIm) $)_{2}\left[\mathrm{Ni}(\mathrm{TMA}-\mathrm{H})_{2}\left(\mathrm{H}_{2} \mathrm{O}\right)_{2}\right]$ and SIMOF-2 (BMIm) $)_{2}\left[\mathrm{Ni}_{3}(\mathrm{TMA}-\mathrm{H})_{4}\left(\mathrm{H}_{2} \mathrm{O}\right)_{2}\right]$ could be achieved by using achiral building blocks in the chiral IL [BMIm] [L-AspH] ${ }^{69 b}$

The structure of SIMOF-1 consists of octahedrally coordinated nickel(II) atoms. Each nickel atom is bound to four trimesate (TMA) anions and two water molecules (Fig. 18). The spatial arrangement of the four linking TMA anions around each nickel atom leads to a pseudo-tetrahedral building unit, which in turn connects to four other metal atoms to form a diamond-type network. The chirality in the structure is represented by a $4_{1}$ screw axis. The pseudotetrahedral units, all of which have the same handedness, form helices and are linked into a three dimensional framework by the bridging ligands. The IL cations are strongly held inside the pores of the substructure.

Later, Zhai et al. reported a novel three-dimensional ferroelectric metal-organic framework, $\left\{(\mathrm{EMI})_{2}\left[\mathrm{Zn}_{3}(1,2,4,5-\right.\right.$ BTC $\left.\left.)_{2}\right] \cdot 2 \mathrm{H}_{2} \mathrm{O}\right\}_{n}(1,2,4,5$-BTC $=1,2,4,5$-benzenetetracarboxylate $)$ by ionothermal synthesis, which defined a new strategy to ferroelectric materials. The ionothermal reaction of $\mathrm{Zn}\left(\mathrm{NO}_{3}\right)_{2} \cdot 6 \mathrm{H}_{2} \mathrm{O}$ and 1,2,4,5-BTC ligands in IL [EMI]Br was carried out at $160^{\circ} \mathrm{C}$ for 7 days to yield colourless block crystals of the product. ${ }^{70}$

The three-dimensional anionic porous framework is constructed from zinc(II) atoms and $\mu_{6}-1,2,4,5$-BTC ligands. The asymmetric unit consists of three crystallographically unique zinc atoms, two 1,2,4,5-BTC ligands, two unique [EMI $]^{+}$cations, and two lattice water molecules, respectively. The three zinc atoms are in distorted tetrahedral environment defined by four carboxylic oxygen atoms from four different 1,2,4,5-BTC ligands. Two independent 1,2,4,5-BTC ligands adopt the $\mu_{6}$-bridging mode with two paracarboxylate groups in a bidentate fashion, while the other two para-carboxylate groups are monodentate (Fig. 18). As a result, the zinc atoms are interconnected through $\mu_{6}-1,2,4,5$-BTC ligands to generate a three-dimensional anionic porous framework.

$\mathrm{Bu}$ et al. further extended the scope of ionothermal synthesis by developing a generalized approach to synthesise homochiral zeolite-like low-connectivity framework materials in which highly 


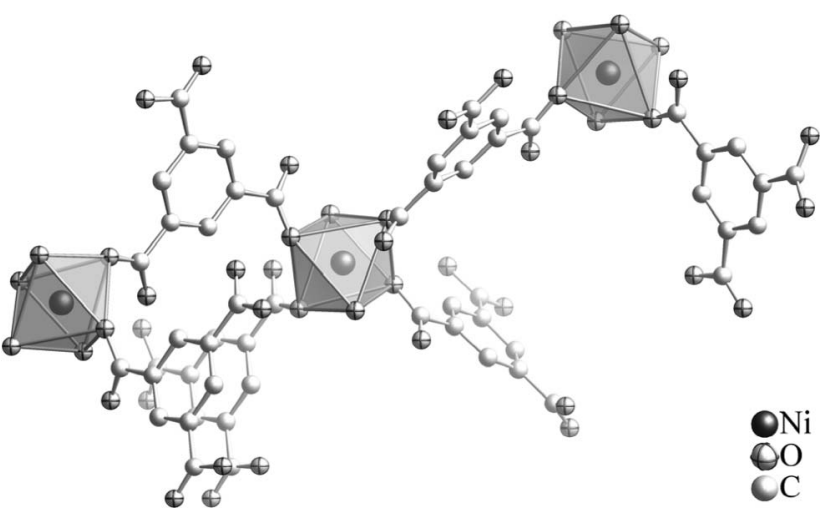

Fig. 18 The substructure of the anionic network of chiral SIMOF-1 showing the octahedral coordination by oxygen atoms around each nickel atom.

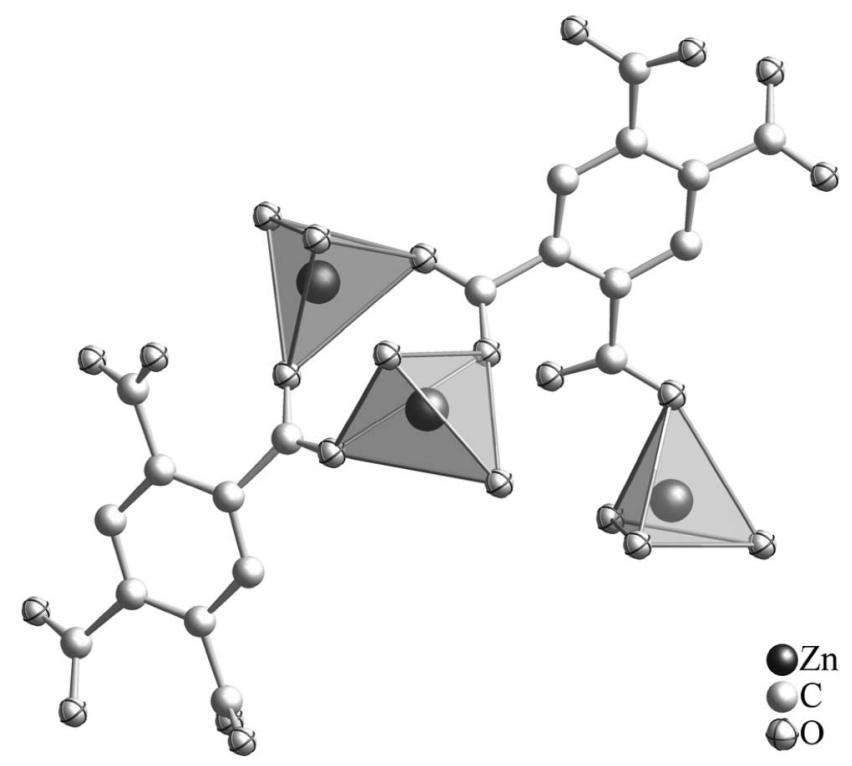

Fig. 19 The polymeric $\left\{\left[\mathrm{Zn}_{3}(1,2,4,5-\mathrm{BTC})_{2}\right] \cdot 2 \mathrm{H}_{2} \mathrm{O}\right\}_{n}^{2 n-}$ anion, highlighting the distorted tetrahedral environment around each zinc atom.

coordinated metal atoms (coordination number $\geq 8$ ) are joined into homochiral three-dimensional tetrahedral frameworks by a templated synthesis. They treated enantiopure D-camphoric acid (D- $\left.\mathrm{H}_{2} \mathrm{cam}\right)$ and achiral 4,4'-oxybis(benzoic acid) $\left(\mathrm{H}_{2} \mathrm{obb}\right)$ with indium(III) nitrate in two different ionic liquids, [EMIm]Es and [BMIm]Ms. This updated synthetic procedure resulted in a number of new open-framework materials that contain eight-coordinated indium(III) atoms as the tetrahedral nodes. Both 4-connected and to a smaller extent 3-connected homochiral frameworks were successfully synthesized, e.g., ALF-1 (EMIm)[In(D-cam) $)_{2}$, ALF$3(\mathrm{EMIm})_{3}\left[\operatorname{In}(\mathrm{obb})_{2}\right] \mathrm{Es}_{2} \cdot \mathrm{H}_{2} \mathrm{O}, \mathrm{ALF}-4 \quad(\mathrm{EMIm})_{2}\left[\operatorname{In}_{2}(\mathrm{D}-\mathrm{cam})_{3}(\mathrm{D}-\right.$ Hcam $\left.)_{2}\right]$ and ALF-5 (BMIm $)_{2}\left[\operatorname{In}_{2}(\text { D-cam })_{3}(\text { D-Hcam })_{2}\right]^{71}$

$\mathrm{Yu}$ et al. represented three new open-framework metal borophosphates, $\left[\mathrm{Na}_{6} \mathrm{Co}_{3} \mathrm{~B}_{2} \mathrm{P}_{5} \mathrm{O}_{21} \mathrm{Cl}\right] \cdot \mathrm{H}_{2} \mathrm{O}$ (JIS-4), $\mathrm{K}_{5} \mathrm{Mn}_{2} \mathrm{~B}_{2} \mathrm{P}_{5} \mathrm{O}_{19}(\mathrm{OH})_{2} \quad(\mathrm{JIS}-5)$ and $\left(\mathrm{NH}_{4}\right)_{8}\left[\mathrm{Co}_{2} \mathrm{~B}_{4} \mathrm{P}_{8} \mathrm{O}_{30}(\mathrm{OH})_{4}\right]$ (JIS-6), synthesised under ionothermal conditions using the ionic liquid [Emim] Br as the solvent. These are the first examples of metalloborophosphate prepared by the ionothermal method. ${ }^{72}$

IL with polyoxometallate (POM) anions are also known. The first POM-based IL was reported by Giannelis et al. ${ }^{74}$ The synthesis was performed by combining a partially deprotonated heteropolyacid $\left[\mathrm{H}_{3-x} \mathrm{PW}_{12} \mathrm{O}_{40}\right]^{x-}$ with quaternary ammonium ions $\left(\mathrm{CH}_{3}\right)\left(\mathrm{C}_{18} \mathrm{H}_{37}\right) \mathrm{N}^{+}\left[\left(\mathrm{CH}_{2} \mathrm{CH}_{2} \mathrm{O}\right)_{n} \mathrm{H}\right]\left[\left(\mathrm{CH}_{2} \mathrm{CH}_{2} \mathrm{O}\right)_{m} \mathrm{H}\right](m+n=15)$. This new family of materials was characterised by electrochemical and thermal analysis. The fluid character and proton transport properties under anhydrous conditions make these IL possible candidates for fuel cell and catalytic applications. Later, Dietz et al. carried out further investigations for the preparation and preliminary characterisation of the other members of this family of aprotic, POM-based IL, and described their potential as organicinorganic hybrid materials. ${ }^{75} \mathrm{Hou}$ et al. and many others promoted this class of materials by adding IL to the list that exhibited excellent catalytic performance in organic synthesis. ${ }^{76-80}$

Shan et al. synthesised several new inorganic IL $^{81}$ consisting of an inorganic polyoxometalate anion with the Keggin structure $^{82}$ and sodium cations, e.g. $\mathrm{Na}_{13}\left[\mathrm{Ln}\left(\mathrm{TiW}_{11} \mathrm{O}_{39}\right)_{2}\right] \cdot x \mathrm{H}_{2} \mathrm{O}$ $(\mathrm{Ln}=\mathrm{La}, \mathrm{Ce}, \mathrm{Pr}, \mathrm{Sm}, \mathrm{Gd}$, Dy, Er, Tm or $\mathrm{Yb}, x=27.1-43.7)$, $\mathrm{Na}_{5}\left[\mathrm{MTiW}_{11} \mathrm{O}_{39}\right] \cdot x \mathrm{H}_{2} \mathrm{O}$ and $\mathrm{Na}_{6}\left[\mathrm{MTiW}_{11} \mathrm{O}_{39}\right] \cdot x \mathrm{H}_{2} \mathrm{O}(\mathrm{M}=\mathrm{Cr}, \mathrm{Mn}$, $\mathrm{Fe}$, or $\mathrm{Zn}, x=27.2-30.2)$. These inorganic IL were characterised by NMR, IR spectroscopy and by elemental analysis. Moreover, their physicochemical properties were also investigated. It was concluded that these IL are almost immiscible with water below room temperature, but the solubility of the IL increases sharply with an increase in temperature. The most significant feature of these IL is that water is their indispensable component and the role of the water molecules in IL is similar to that of crystalline water in hydrated compounds.

\section{Summary and outlook}

The presently known discrete homo- and heterpolynuclear transition-metal complexes and cluster compounds have been reviewed combining the most relevant past and recent developments (see Appendix). A concise description regarding the most recent (ionothermal) synthesis of coordination polymers from IL have also been included. It is concluded that halogenido-aluminate IL could be exploited as an efficient alternative reaction medium for the synthesis of polynuclear metal clusters under mild conditions, which were previously obtained by high-temperature methods. In case of the task-specific IL, the zwitterionic nature of the betaine ligand and the weakly coordinating ability of the bistriflimide anion facilitate the isolation of polynuclear complexes, presumably these structural features give rise to highly favourable lattice energy. Some of the organometallic complexes synthesised from IL were found to be intermediate catalyst precursors. For example, the binuclear palladium complex $[\operatorname{PdBr}(\mu-\mathrm{Br})(\text { bmiy })]_{2}$ acts as an intermediate to synthesise mononuclear $\left[\mathrm{PdBr}_{2}(\mathrm{bmiy})_{2}\right]$, which can catalyse Heck reactions. Similarly, the ruthenium complex $\left[\mathrm{RuCl}_{2}\left(\eta^{6} \text {-arene }\right)\right]_{2}$ represents an ideal precursor for both aqueous and ionic liquid biphasic catalysis.

IL perform multiple roles for the ionothermal synthesis of coordination polymers, independently in three different ways: (i) solvent and cationic structure-directing agent, (ii) solvent only, and (iii) solvent and cationic/anionic structure-directing agents. These three different functions of IL further extend the applicability of this approach and make it possible to synthesise a variety of homochiral and achiral metal organic frameworks with various compositions and structures. 
From this review, we anticipate that the reader will get the general impression that the synthesis of polynuclear transitionmetal complexes using or in the presence of IL has already showed some promise, but substantial work still lies ahead. We believe that the present achievements and many projected future prospects in this area will have fundamental and practical impacts on transition metal chemistry.

\section{Acknowledgements}

The financial support from the Higher Education Commission of Pakistan (HEC), the German Academic Exchange Service (DAAD), and the Max Planck Society (MPG) is appreciatively acknowledged.

\section{Appendix}

Table 1 List of abbreviations for different ionic liquids

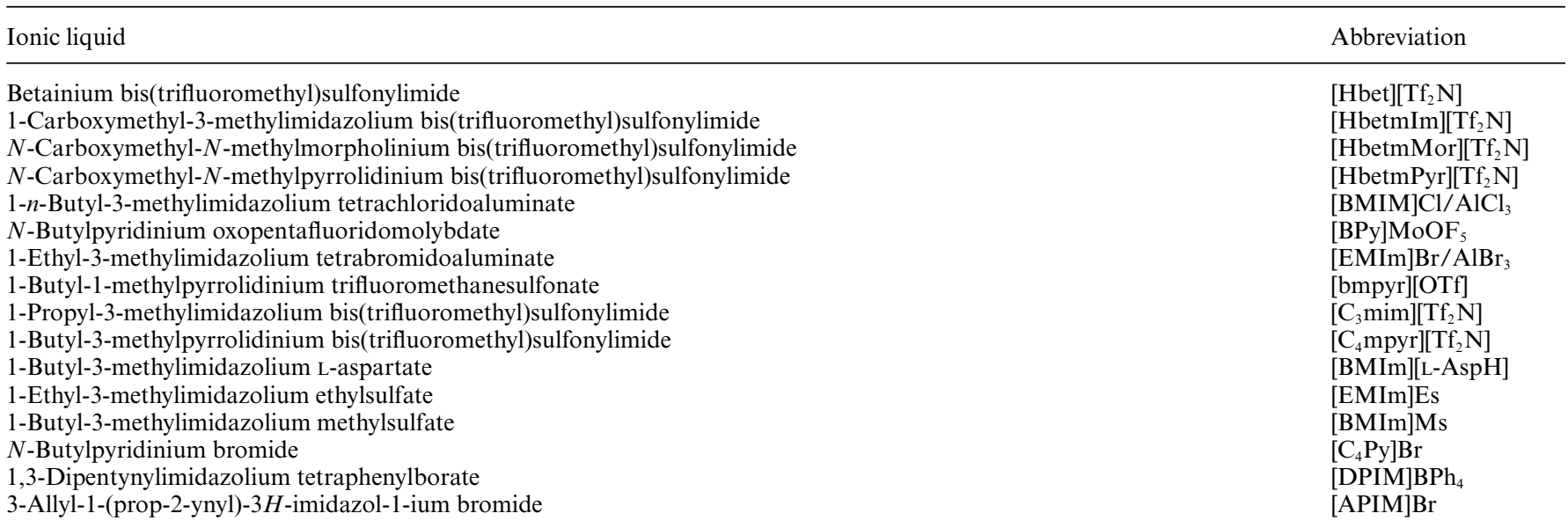

Table 2 Selected discrete homo- and heteropolynuclear transition-metal complexes and clusters synthesised from IL

\begin{tabular}{|c|c|c|}
\hline Complex & Nuclearity & Ref. \\
\hline$\left.\left[\mathrm{Cu}_{2} \text { (betmMor }\right)_{4}\right]\left[\mathrm{Tf}_{2} \mathrm{~N}\right]_{4}$ & 2 & $60 b$ \\
\hline$\left[\mathrm{Cu}_{2}(\text { betmPyr })_{4}\left(\mathrm{H}_{2} \mathrm{O}\right)_{2}\right]\left[\mathrm{Tf}_{2} \mathrm{~N}\right]_{4}$ & 2 & $60 b$ \\
\hline$\left[\mathrm{Cu}_{2}(\text { betmIm })_{4}\left(\mathrm{H}_{2} \mathrm{O}\right)_{2}\right]\left[\mathrm{Tf}_{2} \mathrm{~N}\right]_{4} \cdot \mathrm{H}_{2} \mathrm{O}$ & 2 & $60 b$ \\
\hline$\left[\mathrm{Cd}_{2}(\text { betPy })_{2}\left(\mathrm{H}_{2} \mathrm{O}\right)_{2}\right]\left[\mathrm{Tf}_{2} \mathrm{~N}\right]_{2}$ & 2 & $60 b$ \\
\hline$\left.\left[\mathrm{Eu}_{2} \text { (bet) }\right)_{8}\left(\mathrm{H}_{2} \mathrm{O}\right)_{4}\right]\left[\mathrm{Tf}_{2} \mathrm{~N}\right]_{6}$ & 2 & $48 b$ \\
\hline$\left[\mathrm{Mo}_{2} \mathrm{Te}_{12}\right] \mathrm{I}_{6}$ & 2 & 51 \\
\hline$[\mathrm{BPy}]_{2}\left[\mathrm{Mo}_{2} \mathrm{O}_{4} \mathrm{~F}_{6}\right]$ & 2 & 63 \\
\hline$\left[\{\mathrm{APIM}\} \mathrm{Co}_{2}(\mathrm{CO})_{6}\right] \mathrm{PF}_{6}$ & 2 & $46 b$ \\
\hline$\left[\{\mathrm{APIM}\} \mathrm{Co}_{2}(\mathrm{CO})_{6}\right] \mathrm{B}\left(\mathrm{C}_{6} \mathrm{H}_{5}\right)_{4}$ & 2 & $46 b$ \\
\hline$\left[\mathrm{RuCl}_{2}\left(\eta^{6} \text {-arene }\right)\right]_{2}$ & 2 & $47 c$ \\
\hline$[\mathrm{bmim}] \mathrm{K}\left[\mathrm{Co}(\mathrm{CO})_{4}\right]_{2}$ & 2 & $46 \mathrm{~d}$ \\
\hline$\left[\mathrm{C}_{4} \mathrm{Py}\right] \mathrm{K}\left[\mathrm{Co}(\mathrm{CO})_{4}\right]_{2}$ & 2 & $46 \mathrm{~d}$ \\
\hline $\operatorname{Bis}\{1-[(E)-2$-butenyl]-3-(4-ferrocenylphenyl)-2H-imidazol-2-ylidene $\}$ gold(I) tetrafluoroborate & 3 & $46 c$ \\
\hline$\left[\{\mathrm{DPIM}\}\left\{\mathrm{Co}_{2}(\mathrm{CO})_{6}\right\}_{2}\right] \mathrm{BPh}_{4}$ & 4 & 66 \\
\hline$\left[\mathrm{Mn}_{4}(\text { bet })_{10}\left(\mathrm{H}_{2} \mathrm{O}\right)_{4}\right]\left[\mathrm{Tf}_{2} \mathrm{~N}\right]_{8}$ & 4 & $48 a$ \\
\hline$\left[\mathrm{Zn}_{4}(\text { bet })_{10}\left(\mathrm{H}_{2} \mathrm{O}\right)_{2}\right]\left[\mathrm{Tf}_{2} \mathrm{~N}\right]_{8}$ & 4 & $48 a$ \\
\hline$\left[\mathrm{Ni}_{5}(\text { bet })_{12}\left(\mathrm{H}_{2} \mathrm{O}\right)_{6}\right]\left[\mathrm{Tf}_{2} \mathrm{~N}\right]_{10}$ & 5 & $48 a$ \\
\hline$\left[\left(\mathrm{Pb}_{4} \mathrm{O}\right) \mathrm{Pb}(\mathrm{OH})(\text { bet })_{8}\left(\mathrm{Tf}_{2} \mathrm{~N}\right)_{3}\right]\left[\mathrm{Tf}_{2} \mathrm{~N}\right]_{4} \cdot \mathrm{MeOH}$ & 5 & $48 a$ \\
\hline $\mathrm{Bi}\left[\mathrm{Mo}_{5} \mathrm{Cl}_{13}\right] \mathrm{Cl}$ & 5 & 53 \\
\hline $\operatorname{Im}_{4}\left[\left(\mathrm{Zr}_{6} \mathrm{C}\right) \mathrm{Cl}_{18}\right]$ & 6 & $43 b$ \\
\hline $\mathrm{Im}_{5}\left[\left(\mathrm{Zr}_{6} \mathrm{~B}\right) \mathrm{Cl}_{18}\right] \cdot \mathrm{C}_{6} \mathrm{H}_{5} \mathrm{CH}_{3} \cdot 2 \mathrm{CH}_{3} \mathrm{CN}$ & 6 & 41 \\
\hline $\mathrm{BiCl}\left[\mathrm{Mo}_{6} \mathrm{Cl}_{14}\right]$ & 6 & 53 \\
\hline $\mathrm{Im}_{4}\left[\left(\mathrm{Zr}_{6} \mathrm{Fe}\right) \mathrm{Cl}_{18}\right]$ & 7 & 40 \\
\hline $\mathrm{Im}_{5}\left[\left(\mathrm{Zr}_{6} \mathrm{Mn}\right) \mathrm{Cl}_{18}\right] \cdot 1.5 \mathrm{CH}_{3} \mathrm{CN}$ & 7 & 40 \\
\hline $\mathrm{Im}_{5}\left[\left(\mathrm{Zr}_{6} \mathrm{Mn}\right) \mathrm{Cl}_{18}\right] \cdot \mathrm{C}_{6} \mathrm{H}_{5} \mathrm{CH}_{3} \cdot 2 \mathrm{CH}_{3} \mathrm{CN}$ & 7 & $43 b$ \\
\hline$[\mathrm{EMIm}]_{4}\left[\left(\mathrm{Zr}_{6} \mathrm{Fe}\right) \mathrm{Br}_{18}\right]$ & 7 & 44 \\
\hline
\end{tabular}




\section{References}

1 T. Welton, Chem. Rev., 1999, 99, 2071-2084

2 P. Wasserscheid and W. Keim, Angew. Chem., 2000, 112, 3926-3945; P. Wasserscheid and W. Keim, Angew. Chem., Int. Ed., 2000, 39, 37723789.

3 K. R. Seddon, J. Chem. Technol. Biotechnol., 1997, 68, 351-356.

4 P. Wasserscheid and T. Welton, Ionic Liquids in Synthesis, Wiley-VCH, New York, 2007.

5 W. M. Reichert, J. D. Holbrey, K. B. Vigour, T. D. Morgan, G. A. Broker and R. D. Rogers, Chem. Commun., 2006, 4767-4779.

6 J. D. Holbrey, K. B. Vigour, W. M. Reichert and R. D. Rogers, J. Chem. Crystallogr., 2006, 36, 799-804.

7 K. Jin, X. Huang, L. Pang, J. Li, A. Appel and S. Wherland, Chem. Commun., 2002, 2872-2873.

8 A. Babai and A. V. Mudring, Chem. Mater., 2005, 17, 6230-6238.

9 (a) S. Tang, A. Babai and A. V. Mudring, Angew. Chem., 2008, 120, 7743-7746; S. Tang, A. Babai and A. V. Mudring, Angew. Chem., Int. Ed., 2008, 47, 7631-7634; (b) A. Babai and A. V. Mudring, Inorg. Chem., 2006, 45, 4874 4876; (c) A. Getsis, S. Tang and A. V. Mudring, Eur. J. Inorg. Chem., 2010, 2172-2177.

10 A. Babai and A. V. Mudring, J. Alloys Compd., 2006, 418, 122-127.

11 A. Babai and A. V. Mudring, Z. Anorg. Allg. Chem., 2006, 632, 19561958.

12 A. E. Visser, R. P. Swatloski, W. M. Reichert, R. Mayton, S. Sheff, A. Wierzbicki, J. H. Davis and R. D. Rogers, Environ. Sci. Technol., 2002, 36, 2523-2529.

13 F. Endres, M. Bukowski, R. Hempelmann and H. Natter, Angew. Chem., 2003, 115, 3550-3552; F. Endres, M. Bukowski, R. Hempelmann and H. Natter, Angew. Chem., Int. Ed., 2003, 42, 3428-3430.

14 (a) H. T. Sun, Y. Sakka, H. Gao, Y. Miwa, M. Fujii, N. Shirahata, Z. Bai and J. G. Li, J. Mater. Chem., 2011, 21, 4060-4063; (b) H. T. Sun, Y. Sakka, M. Fujii, N. Shirahata and H. Gao, Opt. Lett., 2011, 36, $100-102$.

15 N. Papageorgiou, Y. Athanassov, M. Armand, P. Bonhôte, H. Pettersson, A. Azam and M. Grätzel, J. Electrochem. Soc., 1996, 143, 3099-3108.

16 K. Lunstroot, K. Driesen, P. Nockemann, C. Görller-Walrand, K. Binnemans, S. Bellayer, J. L. Bideau and A. Vioux, Chem. Mater., 2006, 18, 5711-5715.

17 P. Nockemann, B. Thijs, N. Postelmans, K. Van Hecke, L. Van Meervelt and K. Binnemans, J. Am. Chem. Soc., 2006, 128, 13658-13659.

18 Y. Yoshida, J. Fujii, G. Saito, T. Hiramatsu and N. Sato, J. Mater Chem., 2006, 16, 724-727.

19 I. J. B. Lin and C. S. Vasam, J. Organomet. Chem., 2005, 690, 3498-3512.

20 M. Hasan, I. V. Kozhevnikov, M. R. H. Siddiqui, A. Steiner and N. Winterton, Inorg. Chem., 1999, 38, 56375641.

21 (a) R. E. D. Sesto, T. M. McCleskey, A. K. Burrell, G. A. Baker, J. D. Thompson, B. L. Scott, J. S. Wilkes and P. Williams, Chem. Commun., 2008, 447-449; (b) S. Pitula and A. V. Mudring, Chem.-Eur. J., 2010, 16, 3355-3365; (c) B. Mallick, B. Balke, C. Felser and A. V. Mudring, Angew. Chem., 2008, 120, 7747-7750; B. Mallick, B. Balke, C. Felser and A. V. Mudring, Angew. Chem., Int. Ed., 2008, 47, 7635-7638.

22 (a) F. W. Koknat, J. A. Parson and A. Vongvusharintra, Inorg. Chem., 1974, 13, 1699-1702; (b) Y. Park and M. G. Kanatzidis, Chem. Mater., 1991, 3, 781-783; (c) J. Beck and M. Hengstmann, Z. Anorg. Allg. Chem., 1998, 624, 433-437.

23 M. Ruck, Z. Anorg. Allg. Chem., 1995, 621, 2034-2042.

24 M. Ruck, Z. Anorg. Allg. Chem., 1997, 623, 1535-1541.

25 M. Ruck, Z. Anorg. Allg. Chem., 1997, 623, 1583-1590.

26 M. Ruck, Z. Anorg. Allg. Chem., 1997, 623, 1591-1598.

27 M. Ruck and R. M. Heich, Z. Anorg. Allg. Chem., 2000, 626, 24492456.

28 A. Günther, F. Steden and M. Ruck, Z. Anorg. Allg. Chem., 2008, 634, 423-430.

29 B. Wahl, L. Kloo and M. Ruck, Z. Anorg. Allg. Chem., 2009, 635, 1979-1985.

30 M. Ruck, Solid State Sci., 2001, 3, 369-375.

31 (a) B. Wahl, L. Kloo and M. Ruck, Angew. Chem., 2008, 120, 39963999; B. Wahl, L. Kloo and M. Ruck, Angew. Chem., Int. Ed., 2008, 47, 3932-3935; (b) B. Wahl and M. Ruck, Z. Anorg. Allg. Chem., 2008, 634, 2267-2275.

32 (a) R. D. Adams, J. E. Babin and M. Tasi, Angew. Chem., 1987, 99, 691-692; R. D. Adams, J. E. Babin and M. Tasi, Angew. Chem., Int. Ed.
Engl., 1987, 26, 685-686; (b) M. M. Olmstead and P. P. Power, J. Am. Chem. Soc., 1984, 106, 1495-1496.

33 (a) G. Schmid, N. Klein, L. Korste, U. Kreibig and D Schönauer, Polyhedron, 1988, 7, 605-608; (b) F. W. Vergeer, P. Matousek, M. Towrie, P. J. Costa, M. J. Calhorda and F. Hartl, Chem.-Eur. J., 2004, 10, 34513460 .

34 (a) E. J. Welch, N. R. M. Crawford, R. G. Bergman and J. R. Long, J. Am. Chem. Soc., 2003, 125, 11464-11465; (b) S. Cordier, K. Kirakci, D. Méry, C. Perrin and D. Astruc, Inorg. Chim. Acta, 2006, 359, 17051709.

35 (a) H.-J. Meyer, Z. Anorg. Allg. Chem., 1995, 621, 921-924; (b) B. Jung and G. Meyer, Z. Anorg. Allg. Chem., 1992, 610, 15-19; (c) X. Zhao, Y. G. Li, Y. H. Wang and E. B. Wang, Transition Met. Chem., 2007, 33, 323-330; (d) S. Chang, Y. F. Qi, E. B. Wang and Z. Zhang, Inorg. Chim. Acta, 2009, 362, 453-457.

36 C. L. Hussey, Pure Appl. Chem., 1988, 60, 1763-1772.

37 C. L. Hussey, R. Quigley and K. R. Seddon, Inorg. Chem., 1995, 34, 370-377.

38 P. A. Barnard, I. W. Sun and C. L. Hussey, Inorg. Chem., 1990, 29, 3670-3674.

39 R. Quigley, P. A. Barnard, C. L. Hussey and K. R. Seddon, Inorg. Chem., 1992, 31, 1255-1261.

40 C. E. Runyan and T. Hughbanks, J. Am. Chem. Soc., 1994, 116, 79097910.

41 Y. Tian and T. Hughbanks, Inorg. Chem., 1995, 34, 6250-6254.

42 J. D. Harris and T. Hughbanks, J. Am. Chem. Soc., 1997, 119, 94499459.

43 (a) D. Sun and T. Hughbanks, Inorg. Chem., 1999, 38, 992-997; (b) D. Sun and T. Hughbanks, Inorg. Chem., 2000, 39, 1964-1968.

44 J. B. Willems, H. W. Rohm, C. Geers and M. Köckerling, Inorg. Chem., 2007, 46, 6197-6203.

45 H. Sakamoto, Y. Watanabe and T. Saito, Inorg. Chem., 2006, 45, 4578 4579.

46 (a) P. J. Dyson, Transition Met. Chem., 2002, 27, 353-358; (b) H. Schottenberger, K. Wurst, U. E. I. Horvath, S. Cronje, J. Lukasser, J. Polin, J. M. McKenzie and H. G. Raubenheimer, Dalton Trans., 2003, 4275-4281; (c) U. E. I. Horvath, G. Bentivoglio, M. Hummel, H. Schottenberger, K. Wurst, M. J. Nell, C. E. J. van Rensburg, S. Cronje and H. G. Raubenheimer, New J. Chem., 2008, 32, 533-539; (d) F. G. Deng, B. Hu, W. Sun and C. G. Xia, Dalton Trans., 2008, 5957-5961; (e) L. Xu, W. Chen and J. Xiao, Organometallics, 2000, 19, 1123-1127.

47 (a) P. J. Dyson, Coord. Chem. Rev., 2004, 248, 2443-2458; (b) T. J. Geldbach, G. Laurenczy, R. Scopelliti and P. J. Dyson, Organometallics, 2006, 25, 733-742; (c) T. J. Geldbach and P. J. Dyson, J. Am. Chem. Soc., 2004, 126, 8114-8115.

48 (a) P. Nockemann, B. Thijs, K. Van Hecke, L. Van Meervelt and K. Binnemans, Cryst. Growth Des., 2008, 8, 1353-1363; (b) P. Nockemann, B. Thijs, K. Lunstroot, T. N. Parac-Vogt, C. Görller-Walrand, K. Binnemans, K. Van Hecke, L. Van Meervelt, S. Nikitenko, J. Daniels, C. Hennig and R. Van Deun, Chem.-Eur. J., 2009, 15, 1449-1461.

49 E. Ahmed, D. Köhler and M. Ruck, Z. Anorg. Allg. Chem., 2009, 635, 297-300.

50 E. Ahmed, M. Groh and M. Ruck, Eur. J. Inorg. Chem., 2010, 5294 5297.

51 E. Ahmed, E. Ahrens, M. Heise and M. Ruck, Z. Anorg. Allg. Chem., 2010, 636, 2602-2606.

52 E. Ahmed, E. Ahrens, M. Heise and M. Ruck, Z. Anorg. Allg. Chem., 2010, 636, 2053.

53 E. Ahmed, E. Ahrens, M. Heise and M. Ruck, Z. Anorg. Allg. Chem., 2011, 637, 961-964.

54 M. Antonietti, D. B. Kuang, B. Smarsly and Y. Zhou, Angew. Chem., 2004, 116, 5096-5100; M. Antonietti, D. B. Kuang, B. Smarsly and Y. Zhou, Angew. Chem., Int. Ed., 2004, 43, 4988-4992.

55 (a) Z. Ma, J. Yu and S. Dai, Adv. Mater., 2010, 22, 261-285; (b) Y. Zhou, Curr. Nanosci., 2005, 1, 35-42.

56 A. Taubert, Acta Chim. Slov., 2005, 52, 183-186.

57 A. Taubert and Z. H. Li, Dalton Trans., 2007, 723-727.

58 E. R. Parnham and R. E. Morris, Acc. Chem. Res., 2007, 40, 1005-1013.

59 K. Binnemans, Chem. Rev., 2007, 107, 2592-2614.

60 (a) P. Nockemann, R. Van Deun, B. Thijs, D. Huys, E. Vanecht, K. Van Hecke, L. Van Meervelt and K. Binnemans, Inorg. Chem., 2010, 49, 3351-3360; (b) P. Nockemann, B. Thijs, T. N. Parac-Vogt, K. Van Hecke, L. Van Meervelt, B. Tinant, I. Hartenbach, T. Schleid, V. T. Ngan, M. T. Nguyen and K. Binnemans, Inorg. Chem., 2008, 47, 99879999. 
61 (a) V. A. Cocalia, K. E. Gutowski and R. D. Rogers, Coord. Chem. Rev., 2006, 250, 755-764; (b) W. R. Pitner, A. E. Bradley, D. W. Rooney, D. Sanders, K. R. Seddon, R. C. Thied and J. E. Ratter, Green Ind. Appl. Ionic Liquids., 2003, 92, 209-226; (c) P. R. V. Rao, K. A. Venkatesan and T. G. Srinivasan, Prog. Nucl. Energy, 2008, 50, 449-455.

62 J. Beck, J. Solid State Chem., 1996, 125, 165-170.

63 T. Kanatani, K. Matsumoto and R. Hagiwara, Eur. J. Inorg. Chem., 2010, 1049-1055.

64 V. Kolesnichenko, J. J. Luci, D. C. Swenson and L. Messerle, J. Am. Chem. Soc., 1998, 120, 13260-13261.

65 M. Weisser, S. Tragl and H.-J. Meyer, Z. Anorg. Allg. Chem., 2006, 632, $1885-1889$.

66 Z. Fei, D. Zhao, R. Scopelliti and P. J. Dyson, Organometallics, 2004, 23, $1622-1628$.

67 S. Böschen and H.-L. Keller, Z. Kristallogr., 1992, 200, 305-315.

68 H. Schäfer and H. G. Schnering, Angew. Chem., 1964, 76, 833-849.

69 (a) E. R. Cooper, C. D. Andrews, P. S. Wheatley, P. B. Webb, P. Wormald and R. E. Morris, Nature, 2004, 430, 1012-1016; (b) Z. Lin, A. M. Z. Slawin and R. E. Morris, J. Am. Chem. Soc., 2007, 129, 4880-4881; (c) R. E. Morris, Angew. Chem., 2008, 120, 450-452; R. E. Morris, Angew. Chem., Int. Ed., 2008, 47, 442-444; (d) R. E. Morris and X. Bu, Nat. Chem., 2010, 2, 353-361; (e) R. E. Morris, Chem. Commun., 2009, 2990-2998.

70 W. J. Ji, Q. G. Zhai, S. N. Li, Y. C. Jiang and M. C. Hu, Chem. Commun., 2011, 47, 3834-3836.
71 J. Zhang, S. Chen and X. Bu, Angew. Chem., 2008, 120, 5514-5517; J. Zhang, S. Chen and X. Bu, Angew. Chem., Int. Ed., 2008, 47, 5434 5437.

72 T. Su, H. Xing, J. Xu, J. Yu and R. Xu, Inorg. Chem., 2011, 50, 10731078.

73 H. Fu, Y. Li, Y. Lu, W. Chen, Q. Wu, J. Meng, X. Wang, Z. Zhang and E. Wang, Cryst. Growth Des., 2011, 11, 458-465.

74 A. B. Bourlinos, K. Raman, R. Herrera, Q. Zhang, L. A. Archer and E. P. Giannelis, J. Am. Chem. Soc., 2004, 126, 15358-15359.

75 P. G. Rickert, M. R. Antonio, M. A. Firestone, K. A. Kubatko, T. Szreder, J. F. Wishart and M. L. Dietz, J. Phys. Chem. B, 2007, 111, 4685-4692.

76 H. Li, Z. Hou, Y. Qiao, B. Feng, Y. Hu, X. Wang and X. Zhao, Catal. Commun., 2010, 11, 470-475.

77 H. Li, Y. Qiao, L. Hua, Z. Hou, B. Feng, Z. Pan, Y. Hu, X. Wang, X. Zhao and Y. Yu, Chem CatChem, 2010, 2, 1165-1170.

78 W. Huang, W. Zhu, H. Li, H. Shi, G. Zhu, H. Liu and G. Chen, Ind. Eng. Chem. Res., 2010, 49, 8998-9003.

79 Y. Leng, J. Wang, D. Zhu, X. Ren, H. Ge and L. Shen, Angew. Chem., 2008, 121, 174-177; Y. Leng, J. Wang, D. Zhu, X. Ren, H. Ge and L. Shen, Angew. Chem., Int. Ed., 2008, 48, 168-171.

80 A. Corma, S. Iborra, F. X. L. Xamena, R. Montón, J. J. Calvino and C. Prestipino, J. Phys. Chem. C, 2010, 114, 8828-8836.

81 L. Dai, S. Yu, Y. Shan and M. He, Eur. J. Inorg. Chem., 2004, 237-241. 82 J. D. Peter, J. Am. Chem. Soc., 1984, 106, 7677-7687. 